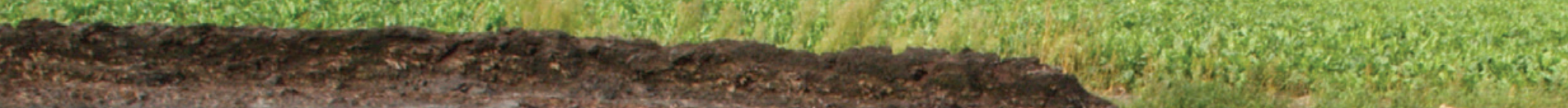

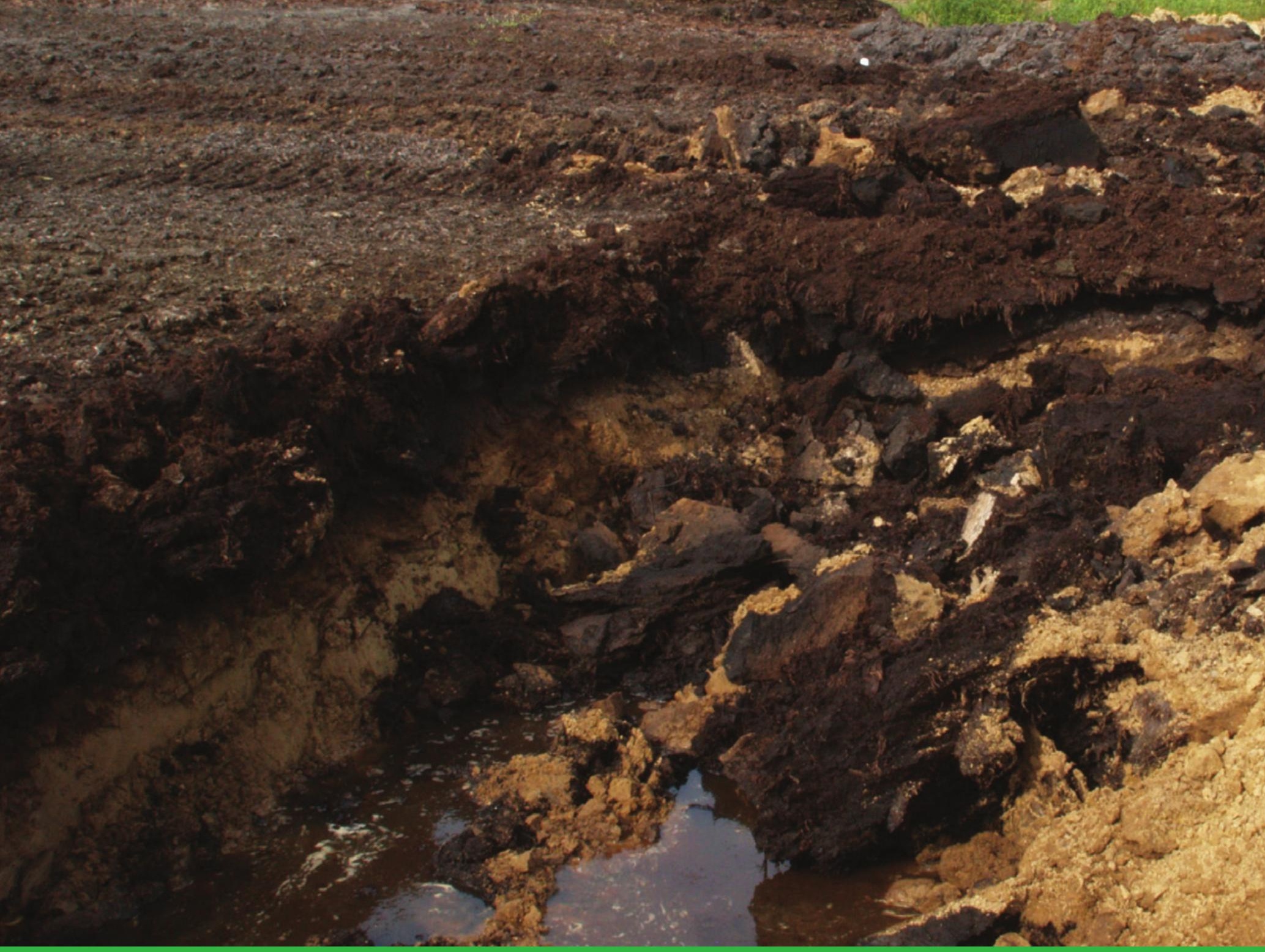

\title{
Inventarisatie GIS-bestanden met informatie over bodemverstoring
}





\section{Inventarisatie GIS-bestanden met informatie over bodemverstoring}

G.J. Maas, F. de Vries, F. Brouwer en N. Heidema

Dit project is uitgevoerd door Wageningen Environmental Research (Alterra) in opdracht van de Rijksdienst voor het Cultureel Erfgoed.

Wageningen Environmental Research

Wageningen, oktober 2016

Rapport 2751

ISSN 1566-7197 
Maas, G.J., F. de Vries, F. Brouwer en N. Heidema, 2016. Inventarisatie GIS-bestanden met informatie over bodemverstoring. Wageningen, Wageningen Environmental Research, Rapport 2751. 34 blz.; 4 fig. ; 12 tab.; 10 ref.

In de bodem zit een schat aan sporen van activiteiten uit het verleden. In ons dichtbevolkte land is de kans groot dat deze waardevolle archeologische resten worden aangetast door grondbewerking en graafwerkzaamheden. Dit rapport geeft een overzicht van geografische bronbestanden die gebruikt kunnen worden om gebieden te lokaliseren waar de bodem reeds verstoord is.

Trefwoorden: bodemverstoring, archeologie, GIS-bestanden, meta-informatie

Dit rapport is gratis te downloaden van http://dx.doi.org/10.18174/392725 of op www.wur.nl/environmental-research (ga naar 'Wageningen Environmental Research' in de grijze balk onderaan). Wageningen Environmental Research verstrekt geen gedrukte exemplaren van rapporten.

() 2016 Wageningen Environmental Research (instituut binnen de rechtspersoon Stichting Wageningen Research), Postbus 47, 6700 AA Wageningen, T 03174807 00, E info.alterra@wur.nl, www.wur.nl/environmental-research. Wageningen Environmental Research is onderdeel van Wageningen University \& Research.

- Overname, verveelvoudiging of openbaarmaking van deze uitgave is toegestaan mits met duidelijke bronvermelding.

- Overname, verveelvoudiging of openbaarmaking is niet toegestaan voor commerciële doeleinden en/of geldelijk gewin.

- Overname, verveelvoudiging of openbaarmaking is niet toegestaan voor die gedeelten van deze uitgave waarvan duidelijk is dat de auteursrechten liggen bij derden en/of zijn voorbehouden.

Wageningen Environmental Research aanvaardt geen aansprakelijkheid voor eventuele schade voortvloeiend uit het gebruik van de resultaten van dit onderzoek of de toepassing van de adviezen.

Wageningen Environmental Research Rapport 2751 | ISSN 1566-7197

Foto omslag: Matheijs Pleijter 


\section{Inhoud}

$\begin{array}{ll}\text { Woord vooraf } & 5\end{array}$

$\begin{array}{ll}\text { Samenvatting } & 7\end{array}$

1

$\begin{array}{ll}\text { Inleiding } & 9\end{array}$

1.1 Achtergrond 9

1.2 Projectdoelstelling 9

$\begin{array}{lll}1.3 & \text { Projectresultaat } & 9\end{array}$

$\begin{array}{lll}1.4 & \text { Metadata } & 10\end{array}$

$\begin{array}{lll}1.5 & \text { Vergraven grondenkaart } & 10\end{array}$

2

$\begin{array}{ll}\text { Inventarisatie van registraties bodemverstoring } & 11\end{array}$

$2.1 \quad$ Verzoek om medewerking 11

2.2 Reacties 11

2.3 Speurwerk $\quad 12$

2.4 Samenvattend $\quad 12$

3

$\begin{array}{ll}\text { De verstoringsbronnenkaart } & 13\end{array}$

3.1 GIS-bestanden met meta-informatie $\quad 13$

3.2 Verschillende soorten bronnen $\quad 14$

3.2.1 Bodemkaarten 14

$\begin{array}{ll}3.2 .2 \text { Landgebruikskaarten } & 19\end{array}$

3.2.3 Kaartenbestanden met locatie-specifieke ingrepen $\quad 22$

4 Conclusies en aanbevelingen $\quad 26$

$\begin{array}{ll}\text { Literatuur } & \mathbf{2 7}\end{array}$

$\begin{array}{lll}\text { Bijlage } 1 \text { Leveringsverzoek } & 28\end{array}$

Bijlage 2 Reacties $\quad 29$

Bijlage 3 Handleiding Verstoringsbronnenkaart 30

Bijlage 4 Contactadressen aangeschreven organisaties 31 



\section{Woord vooraf}

Het project Kenniskaart Archeologie van De Rijksdienst voor het Cultureel Erfgoed (RCE) ontwikkelt een digitaal portaal voor bruikbare kennis, onderzoeksmethodieken en kaarten over de archeologie in Nederland. Deze Kenniskaart bevordert een betere afweging van de archeologische belangen binnen de ruimtelijke ordening. Verstoringen in Kaart is een deelproject van de Kenniskaart en is gericht op het in kaart brengen van de plekken in ons land waar geen kans meer is op archeologische resten in de bodem, doordat de bodem is vergraven of omgewoeld. Wat er niet meer is, kunnen we ook niet meer onderzoeken. Kennis over deze locaties voorkomt onnodig archeologisch onderzoek.

Als onderdeel van Verstoringen in Kaart heeft RCE aan Alterra opdracht gegeven een overzicht samen te stellen met GIS-bestanden die mogelijk informatie kunnen verschaffen over verstoring in de bodem als gevolg van menselijke activiteiten. In een later stadium volgen projecten waarin methodieken worden ontwikkeld om op basis van deze bestanden voor gebieden de kans op bodemverstoring te bepalen.

Dit rapport beschrijft de bronnen die mogelijk informatie kunnen verschaffen over bodemverstoring. Namens de opdrachtgever trad Michel Lascaris op als contactpersoon. Bij Alterra is het project uitgevoerd door Nanny Heidema, Fokke Brouwer, Gilbert Maas en Folkert de Vries. We bedanken collega Joop Okx voor het uitvoeren van een interne review van dit rapport. 


\section{Samenvatting}

Dit onderzoek vindt plaats in het kader van het project Verstoringen in Kaart dat deel uitmaakt van het programma Kenniskaart Archeologie. Dit programma beoogt het bevorderen van een betere afweging van de archeologische belangen binnen de ruimtelijke ordening. Het project Verstoringen in Kaart draagt hieraan bij door 'gereedschap' ter beschikking te stellen dat helder maakt waar archeologisch onderzoek noodzakelijk is.

In 2014 is door Alterra (Maas et al. 2014) in een businesscasestudy gezocht naar de mogelijkheden om voor heel Nederland op basis van bestaande bronbestanden de kans op bodemverstoring in kaart te brengen. De conclusie van dit onderzoek was dat de bronnen naar aard en kwaliteit zo ver uiteenlopen dat het niet zinvol is om binnen aanvaardbare grenzen van tijd/geld een bruikbare verstoringskansenkaart voor heel Nederland te kunnen maken. Wel bieden de kaartbronnen de gebruiker informatie om in kleinere gebieden de verwachte bodemverstoring in kaart te brengen.

Het doel van dit project is een digitaal geografisch overzicht samen te stellen van bestaande landelijke, regionale en lokale datasets waaruit informatie kan worden afgeleid over bodemverstoring. Door reguliere grondbewerkingen is de bodem van landbouwgronden tot ca. $30 \mathrm{~cm}$ beneden maaiveld (30 cm - mv.) beïnvloed, eventueel aanwezige sporen van archeologie in deze bouwvoor zijn uitgewist of ernstig verstoord. In dit project spreken we van bodemverstoring wanneer de bodemlagen onder de bouwvoor van $30 \mathrm{~cm}$ door bewerkingen zijn geroerd of omgewoeld. De aanwezige archeologie in deze lagen kan dan eveneens zijn aangetast.

Het project heeft geresulteerd in de 'Verstoringsbronnenkaart', een GIS-tool waarmee meta-informatie wordt ontsloten van landelijke en provinciale GIS-bestanden. Dit rapport beschrijft op welke wijze de inventarisatie is uitgevoerd en welke gegevens beschikbaar zijn. Informatie over bodemverstoring in het landelijk gebied is te vinden in of af te leiden van bodemkaarten en landgebruikskaarten en bestanden met de ligging van groeves, ontgrondingen en gronddepots. Ook bestanden met de tracés van transportleidingen en grote ingrijpende infrastructurele werken zijn interessant. Maar helaas zijn deze bestanden niet beschikbaar of er is geen meta-informatie. De aangemerkte bestanden zijn veelal te benaderen via het Nationaal of Provinciaal Georegister. De inventarisatie heeft helaas niet geresulteerd in een compleet overzicht van gebieden met ingrepen in de bodemopbouw. Belangrijke instanties met projecten in het landelijk gebied, zoals Rijkswaterstaat en waterschappen, beschikken niet over een gestructureerd overzicht met ingrepen. 


\section{$1 \quad$ Inleiding}

\section{$1.1 \quad$ Achtergrond}

Dit onderzoek vindt plaats in het kader van het project Verstoringen in Kaart dat deel uitmaakt van het programma Kenniskaart Archeologie. Dit programma moet kennis genereren voor een effectieve en doelmatige selectie van locaties waar waardevolle archeologie zou kunnen voorkomen. Het project Verstoringen in Kaart draagt hieraan bij door 'gereedschap' ter beschikking te stellen dat helder maakt waar archeologisch onderzoek noodzakelijk is.

In 2014 is door Alterra (Maas et al. 2014) in een businesscasestudy gezocht naar de mogelijkheden om voor heel Nederland op basis van bestaande bronbestanden de kans op bodemverstoring in kaart te brengen (fase I). De conclusie van dit onderzoek was dat de bronnen naar aard en kwaliteit zo ver uiteen lopen dat het niet zinvol is om binnen aanvaardbare grenzen van tijd/geld een bruikbare verstoringskansenkaart voor heel Nederland te kunnen maken. Wel bieden de kaartbronnen de gebruiker informatie om in kleinere gebieden de verwachte bodemverstoring in kaart te brengen.

Het RCE heeft daarop besloten geen landsdekkende kaart met de verwachte verstoring te maken, maar een kaart/overzicht met beschikbare bronnen met informatie over bodemverstoring met, in een toelichting bij de data (metadata), informatie over de bruikbaarheid en kwaliteit van de gegevens.

\subsection{Projectdoelstelling}

Het doel van dit project (fase II) is een digitaal geografisch overzicht te maken van bestaande landelijke, regionale en lokale datasets met gegevens over de verstoring van de bodem in het buitengebied. Het gaat om digitale uniforme registraties van bodemverstoringen die - indien relevant - (periodiek) worden bijgehouden. Informatie die betrekking heeft op de bebouwde omgeving maakt geen deel uit van dit overzicht. De toelichting bij de datasets (metadata) verschaft informatie over de herkomst, de kwaliteit, beschikbaarheid, betrouwbaarheid en bruikbaarheid van de data voor het in beeld brengen van bodemverstoringen.

Door reguliere grondbewerkingen is de bodem van landbouwgronden tot $\mathrm{ca} .30 \mathrm{~cm}$ beneden maaiveld (30 cm - mv.) beïnvloed, eventueel aanwezige sporen van archeologie in deze bouwvoor zijn uitgewist of ernstig verstoord. In dit project spreken we van bodemverstoring wanneer de bodemlagen onder de bouwvoor van $30 \mathrm{~cm}$ door bewerkingen zijn geroerd of omgewoeld. De aanwezige archeologie in deze lagen kan dan eveneens zijn aangetast. De beïnvloeding door erosie in de hellende terreinen met lössgronden in Zuid-Limburg valt buiten de scope van dit project.

\subsection{Projectresultaat}

Het projectresultaat bestaat uit twee producten:

- Een digitale 'Verstoringsbronnenkaart', een GIS-kaart waarin meta-informatie over de bron is gekoppeld aan de geometrie van het gebied waarop de bron betrekking heeft. De metadata bevatten, conform het Nationaal Georegister, een beschrijving van de gegevens, informatie over de bronhouder (contactinformatie), de actualiteit van de bron en informatie over toegang, gebruik en beperkingen.

- Een toelichting op de verstoringsbronnenkaart met daarin een handleiding bij de GIS-tool en een beschrijving van de resultaten van de inventarisatie van de bronnen. Aanvullend zijn - voor zover de gegevens daarvoor beschikbaar zijn - een indicatie van de kwaliteit en een indicatie van de bruikbaarheid van de bodemverstoringsdata voor de gebruiker gegeven. 


\section{$1.4 \quad$ Metadata}

In de metadata van geografische datasets worden de karakteristieken van de geo-informatie beschreven. De metadata geven de gebruiker inzicht welke geo-informatie beschikbaar is, waar die is te vinden en hoe actueel of betrouwbaar deze informatie is. Voor een uniforme beschrijving is de Nederlandse metadata standaard voor geografie ontwikkeld (ISO 19115, Geonovum, 2015). De standaard metadata-beschrijving omvat de volgende onderdelen:

- Identificatie van de dataset

- Contactgegevens van de beheerder

- Overkoepelende informatie over de metadata

- Geografische dekking en het coördinatensysteem

- Kwaliteit, volledigheid en methode van inwinning

- Inhoud, objectnaam en attributen

- Distributeur, leveringsformaten en leverings- en gebruiksvoorwaarden

De beheerder van de geo-informatie is verantwoordelijk voor een juiste en volledige invulling van de metadata. Bij het aanmaken van metadata volgens het ISO-formaat kan handig gebruik worden gemaakt van de metadata-editor GeoSticker. Deze editor werkt samen met ArcGIS waarbij een deel van de metadata automatisch wordt gegenereerd en bijgewerkt op basis van de data in het GISbestand. Via internet zijn verschillende geo-informatieportals te benaderen. De presentatie van de metadata kan per portal verschillen. Het Nationaal georegister NGR

(http://www.nationaalgeoregister.nl/) en het Provinciaal georegister PGR

(http://www.provinciaalgeoregister.nl/) zijn van belang voor dit project om gegevens over verstoringen in de bodem te achterhalen. Daarnaast kunnen provinciale internetsites informatie over bestanden bevatten.

\subsection{Vergraven grondenkaart}

In 2012 is er door Alterra een GIS-bestand samengesteld met een overzicht van grondbewerkingen, ophogingen en afgravingen, waarbij de opbouw van het bodemprofiel tot ten minste $40 \mathrm{~cm}$ diepte is gewijzigd. Hiervoor is informatie opgevraagd bij instanties en organisaties die werkzaamheden (laten) uitvoeren en/of administreren in verband met vergunningverlening (Brouwer F. en M.M. van der Werff, 2012). Voor deze inventarisatie zijn provincies, waterschappen, natuurorganisaties, de Grondbank, Dienst Rijkswaterstaat en de Nederlandse Gasunie door Alterra benaderd. Als bronhouder van regionale bodemkaarten, meestal schaal $1: 10.000$, heeft Alterra ook eigen bestanden geraadpleegd.

De inventarisatie heeft geresulteerd in de 'vergraven grondenkaart', een uniform GIS-bestand waarin de ingrepen in zeven thema's zijn onderverdeeld:

- Delfstoffen

- Depots

- Natuurontwikkelingsprojecten (Gemodificeerde natuur)

- Verwerkingen

- Transportleidingen

- Bebouwing

- Water

De kaart geeft een momentopname. Om meer inzicht te krijgen in de recente ingrepen, is er behoefte aan een overzicht van de afzonderlijke registraties die actuele informatie kunnen verschaffen over ingrepen in de bodemopbouw. Dat is de centrale vraag in dit rapport. 


\section{Inventarisatie van registraties bodemverstoring}

\subsection{Verzoek om medewerking}

Voor de inventarisatie van de bodemverstoringsbronnen zijn 38 organisaties aangeschreven waarvan, vanwege hun activiteiten, verwacht kan worden dat zij bodemverstoringen registreren. De volgende organisaties zijn daarvoor geselecteerd:

- De Grondbank

- Rijkswaterstaat

- N.V. Nederlandse Gasunie

- Provincies $(n=13)$

- Waterschappen $(n=23)$

De volledige lijst van organisaties en adressen is weergegeven in Bijlage 4.

Naast de informatie die door bovenstaande organisaties beheerd wordt, zijn ook de relevante bronnen die door Alterra en het CBS worden beheerd in de inventarisatie meegenomen.

In samenspraak met de opdrachtgever is een brief opgesteld waarin het doel van de inventarisatie wordt toegelicht en waarin de betreffende organisatie wordt gevraagd of zij bodemverstoringen registreren en zo ja, of zij de metadata van deze registraties ter beschikking willen stellen. De volledige tekst van deze brief is weergegeven in Bijlage 1. Het informatieverzoek is per mail verstuurd naar de betreffende organisaties, voor zover bekend rechtstreeks naar contactpersonen die betrokken zijn bij het onderwerp. Het verzoek is begin juni 2015 verstuurd. Begin september is een herinnering verstuurd. Daarnaast heeft veelvuldig telefonisch contact plaatsgevonden met de aangeschreven organisaties.

\section{$2.2 \quad$ Reacties}

De reacties op het verzoek om informatie over registraties van bodemverstoringen zijn in acht categorieën weergegeven in Tabel 1 .

Tabel 1 Reacties op het verzoek om registraties bodemverstoringsinformatie.

\begin{tabular}{ll} 
Reactie & Aantal \\
Informatie ontsloten via Nationaal Georegister (NGR) & 2 \\
\hline Informatie ontsloten via een provinciaal geoportaal of Provinciaal Georegister (PGR) & 6 \\
\hline Informatie ontsloten via eigen website & 1 \\
\hline Metadata-file (xml) opgestuurd & 3 \\
\hline Geen metadata beschikbaar & 2 \\
\hline Informatie wordt later opgeleverd & 3 \\
\hline Geen relevante informatie beschikbaar/geregistreerd & 11 \\
\hline
\end{tabular}

De organisaties die hun registraties over bodemverstoringen hebben ontsloten via het Nationaal Georegister NGR zijn de provincie Zuid-Holland en het waterschap Rivierenland. Het NGR (http://nationaalgeoregister.nl/geonetwork/srv/dut/search) is een centrale voorziening voor het beschrijven en ontsluiten van geo-informatie binnen Nederland. Het portaal bevat een overzicht van beschikbare datasets en services. De datasets zijn veelal beschikbaar om te downloaden en er kan gebruik worden gemaakt van de services. 
De meeste provincies (Drenthe, Gelderland, Noord-Holland, Utrecht, Noord-Brabant, Zuid-Limburg) hebben hun registraties bodemverstoringen ontsloten via een provinciaal geoportaal of Provinciaal Georegister (PGR). De provincie Zeeland beschikt over informatie over bodemverstoringen, maar heeft deze niet via internet ontsloten. De metadata-file is ter beschikking gesteld en in het overzicht opgenomen. De provincie Flevoland heeft aangegeven niet te beschikken over registraties van bodemverstoringen. Van de provincies Friesland, Groningen en Overijssel is geen reactie op het verzoek teruggekomen.

Twee organisatie reageerden met de mededeling dat bodemverstoringen wel worden geregistreerd, maar meta-informatie niet beschikbaar is: de Gasunie en het Hoogheemraadschap van Rijnland. Rijkswaterstaat heeft aangegeven op dit moment geen informatie te kunnen leveren. Naar aanleiding van het verzoek is Rijkswaterstaat wel een actie gestart om registraties van bodemverstoringen binnen de organisatie in beeld te brengen. Men heeft aangegeven in een later stadium met informatie over bodemverstoringen naar buiten te komen.

Van de waterschappen hebben, naast het Hoogheemraadschap van Rijnland, vier andere organisaties aangegeven over informatie over bodemverstoringen te beschikken: Aa en Maas, De Dommel, Rivierenland en Rijn \& IJssel. Informatie over bodemverstoringen is via de contactpersoon rechtstreeks te verkrijgen. De metadata zijn opgenomen in het overzicht. Wetterskip Fryslân en Hunze en Aa's hebben aangegeven ten tijde van de inventarisatie nog bezig te zijn met het samenstellen van een overzicht van registraties bodemverstoringen.

Elf waterschappen hebben aangegeven geen relevante informatie m.b.t. bodemverstoring beschikbaar en/of systematisch geregistreerd te hebben. Uit gesprekken met de contactpersonen bij de waterschappen is wel gebleken dat gecontracteerde aannemers een (analoog) beheerregister bijhouden van uitgevoerde ingrepen en beheermaatregelen. Informatie over bodemverstoringen kan hieruit zo mogelijk worden afgeleid. Deze registers kunnen eventueel met tussenkomst van het waterschap bij de betreffende aannemers worden ingezien. Deze informatie is niet opgenomen in het overzicht bodemverstoringsbronnen.

Van zes waterschappen is geen reactie op het verzoek teruggekomen. Ook de grondbank heeft niet gereageerd op het verzoek om bodemverstoringsdata.

\section{$2.3 \quad$ Speurwerk}

Het vermoeden bestond dat de provincies Friesland, Groningen en Overijssel, ondanks het uitblijven van een reactie, als bevoegd gezag in het kader van de Ontgrondingen Wet wel moesten beschikken over registraties van bodemverstoringen. Het Nationaal Georegister (NGR) en het Provinciaal Georegister (PGR) zijn daarop doorzocht. Van alle drie deze provincies zijn relevante registraties van bodemverstoringen gevonden. De meta-informatie van deze registraties is opgenomen in het overzicht bodemverstoringsbronnen.

\subsection{Samenvattend}

Van de 38 aangeschreven organisaties beschikken er 17 over voor het overzicht van bodemverstoringsbronnen relevante registraties. Met uitzondering van Flevoland zijn er provinciale bestanden beschikbaar waaruit informatie kan worden afgeleid over bodemverstoring. Bij 6 van de 23 waterschappen zijn bronnen beschikbaar. Daarnaast zijn er 6 landelijke bestanden waaruit informatie over bodemverstoring kan worden afgeleid.

Een overzicht van alle reacties is weergegeven in Bijlage 2. 


\section{De verstoringsbronnenkaart}

\subsection{GIS-bestanden met meta-informatie}

De inventarisatie heeft geresulteerd in overzichten van bronbestanden op landelijk niveau en op provinciaal en waterschapsniveau. Per categorie is er een GIS-bestand waarin de metadata van de beschikbare bronnenbestanden zijn opgenomen. De meta-informatie van de verschillende bronnen is aangevuld met gegevens die voor het bedoelde gebruik relevant zijn. Tabel 2 geeft een overzicht van de attributen in de overzichtsbestanden.

Tabel 2 Overzicht van de attributen in de GIS-bestanden met meta-informatie.

\begin{tabular}{|c|c|}
\hline Attribuutnaam & Omschrijving \\
\hline Bestandsnaam & Naam van het bronbestand \\
\hline Metadata_url & $\begin{array}{l}\text { URL-verwijzing naar de metadata van het bronbestand (met deze link kan de metadata } \\
\text { van het bronbestand worden geopend). }\end{array}$ \\
\hline Verstoringsinfo & Beschrijving van de informatie die betrekking heeft op verstoring van de bodem. \\
\hline Toepassingsschaal & Het maximale schaalniveau waarop de gegevens nog betrouwbaar zijn \\
\hline Perceelsniveau_opm & Aanduiding of het bestand voldoende betrouwbare perceelinformatie verschaft. \\
\hline Datum_bron & Datum waarop het bronbestand tot stand is gekomen \\
\hline Temporele_dekking_begin & Begindatum van de periode waarover het bronbestand informatie geeft. \\
\hline Temporele_dekking_eind & Einddatum van de periode waarover het bronbestand informatie geeft. \\
\hline Verantw_Organisatie & $\begin{array}{l}\text { Naam van de organisatie die het bestand heeft samengesteld of heeft laten } \\
\text { samenstellen. }\end{array}$ \\
\hline DownloadURL & URL naar het bronbestand om het te kunnen downloaden. \\
\hline Bestellen & Verwijzing naar de organisatie om het bestand te bestellen. \\
\hline DatasetURL1 & $\begin{array}{l}\text { URL om het bronbestand via WMS (Web Map Service) in GIS-applicatie te kunnen } \\
\text { gebruiken. }\end{array}$ \\
\hline DatasetURL2 & $\begin{array}{l}\text { URL om het bronbestand via WFS (Web Feature Service) in GIS-applicatie te kunnen } \\
\text { gebruiken. }\end{array}$ \\
\hline Metadata_unieke_ID & $\begin{array}{l}\text { Uniek identificatienummer van de metadata van het bronbestand (met dit nummer kan } \\
\text { het metadatabestand eventueel op internet worden gezocht). }\end{array}$ \\
\hline
\end{tabular}

$\mathrm{Er}$ is een aantal attributen met URL's. Een URL kan na verloop van tijd ongeldig worden of door de bronhouder worden gewijzigd. Wanneer dat gebeurt, werkt de link niet meer. Met behulp van de unieke ID's in de twee laatste kolommen kan het bestand dan waarschijnlijk op internet nog wel worden gevonden. Naast de drie GIS-bestanden met landelijke, provinciale en waterschapsbronnen bevat de samengestelde Verstoringsbronnenkaart GIS-bestanden met de begrenzingen van gedetailleerde bodemkaarten (zie 3.2.1.2), de begrenzingen van vergravingen in de provincie NoordBrabant en een landelijk bestand met draindieptes in landbouwpercelen. In Bijlage 3 is een beknopte handleiding opgenomen voor het gebruik van de verstoringsbronnenkaart. 


\subsection{Verschillende soorten bronnen}

De bronbestanden waarvan meta-informatie is ontsloten, zijn in te delen in een aantal categorieën:

1. Bodemkaarten, waarbij de informatie over bodemverstoring is verkregen middels een gebiedsdekkende bodemkartering volgens een standaard bodemclassificatie, inclusief richtlijnen voor het karteren van bodemverstoringen.

2. Landgebruikskaarten, waarbij het landgebruik een indicatie is voor het mogelijk voorkomen van bodemverstoring. We onderscheiden daarin twee soorten informatie:

a. het landgebruik kan rechtstreeks vertaald worden in een mogelijke bodemverstoring, zoals een baggerdepot in het CBS-bestand (BBG_2010);

b. een mogelijke bodemverstoring wordt afgeleid van de teeltmethode van het agrarisch landgebruik, zoals boomteelt in het LGN7-bestand.

3. Kaartbestanden met informatie over bodemingrepen op specifieke locaties zoals ontgrondingen in de provinciale registraties.

In de volgende paragrafen worden de verschillende bronnen toegelicht. Per bron wordt aangegeven in welk attribuut de informatie over bodemverstoring ligt opgeslagen, worden de onderdelen beschreven (legenda) en wordt, voor zover mogelijk, een vertaling gemaakt naar diepte en frequentie van de bodemverstoring.

\subsubsection{Bodemkaarten}

\subsubsection{Bodemkaart van Nederland 1:50.000}

De Bodemkaart van Nederland 1:50.000 beschrijft de bodem van Nederland volgens de bodemclassificatie van Nederland (De Bakker en Schelling, 1989). In het bestand is naast informatie over het bodemtype, de bodemtextuur en de grondwatertrap ook informatie opgenomen over verstoringen van de bodem. Er worden twee groepen 'vergravingen' onderscheiden:

1. een vergraving waarbij het bodemprofiel zodanig verstoord is dat het nog als bodemtype geclassificeerd kan worden binnen de Bodemclassificatie van Nederland (De bakker en Schelling, 1989);

2. een vergraving waarbij de bodem zodanig verstoord is dat classificatie niet meer mogelijk is.

De betrouwbaarheid van de Bodemkaart van Nederland 1:50.000 uitgedrukt in de 'zuiverheid van de kaartvlakken' heeft een streefwaarde van 70\%. Zuiverheid is gedefinieerd als het oppervlaktepercentage van een kaartvlak waarbinnen de gronden voldoen aan alle of aan een gedeelte van de classificatiecriteria die op de kaart voor de gronden gelden die in de legenda zijn omschreven (Marsman \& De Gruijter, 1982). Voor deze kaart is een uitgebreide veldinventarisatie uitgevoerd, waarbij grondboringen werden verricht met een dichtheid van 10 à 15 boringen per 100 ha. De kaart is oorspronkelijk opgenomen op een analoge topografische kaart 1:25.000. Deze analoge kaarten zijn gegeneraliseerd naar een kaartschaal 1:50.000, op transparante calques gezet en vervolgens vanaf de calques gedigitaliseerd. De minimumoppervlakte van kaartvlakken bedraagt ca. 5 ha. De bodemkaart is in de periode 1960-1995 samengesteld. De inventarisatie van de vergravingen dateert ook uit deze periode. Later uitgevoerde ingrepen staan dus niet op de bodemkaart. In de afgelopen decennia, dus na de opname van de bodemkaart, zijn in landbouwgebieden allerlei cultuurtechnische werken uitgevoerd in verband met bodemprofielverbetering, kavelvergroting en verbetering van de ontwatering. De landelijke bodemkaart geeft dus niet een volledig overzicht van de gebieden met vergraven gronden.

\section{Ad 1}

Gronden met een classificeerbaar bodemprofiel worden als vergraven aangemerkt als tussen 0 en $40 \mathrm{~cm}-\mathrm{mv}$ en doorgaand tot dieper dan $40 \mathrm{~cm}-\mathrm{mv}$ een heterogene laag van ten minste $20 \mathrm{~cm}$ dik wordt aangetroffen. Deze gronden zijn weliswaar verwerkt tot dieper dan $30 \mathrm{~cm}-\mathrm{mv}$, maar de bodemlagen zijn nog zodanig goed herkenbaar dat het oorspronkelijk bodemtype bepaald kan worden. Er worden vier typen 'vergravingen' onderscheiden. In Tabel 3 worden achtereenvolgens de attribuutnaam waaronder de informatie in de database van de bodemkaart is opgeslagen, de bijbehorende legenda-informatie en de diepte en frequentie van de vergravingen omschreven. De vergravingsdiepte bij deze onderscheidingen varieert van 40 à $50 \mathrm{~cm}$ tot meer dan $1 \mathrm{~m}$. 
Tabel 3 Omschrijving legenda vergraven gronden Bodemkaart van Nederland 1:50.000 met een classificeerbaar bodemprofiel (attribuut SCHOP).

\begin{tabular}{|c|c|c|c|c|c|c|}
\hline $\begin{array}{l}\text { Attribuut- } \\
\text { /kolomnaam }\end{array}$ & $\begin{array}{l}\text { Legenda } \\
\text { symbool }\end{array}$ & $\begin{array}{l}\text { Legenda } \\
\text { tekst }\end{array}$ & Legenda omschrijving & $\begin{array}{l}\text { Diepte } \\
\text { min. }\end{array}$ & $\begin{array}{l}\text { Diepte } \\
\text { max. }\end{array}$ & Frequentie \\
\hline $\mathrm{SCHOP}$ & $\longrightarrow$ & $\mathrm{F}$ & $\begin{array}{l}\text { Terreinen waarbij het bodemprofiel is } \\
\text { omgewerkt tot een heterogeen } \\
\text { mengsel. (bijv. mengwoelen, } \\
\text { diepploegen) }\end{array}$ & $40 \mathrm{~cm}$ & $>40 \mathrm{~cm}$ & Ten minste 1 keer \\
\hline $\mathrm{SCHOP}$ & $\downarrow$ & G & $\begin{array}{l}\text { Gronden, die lokaal door afgraving } \\
\text { zijn verlaagd, bijvoorbeeld door } \\
\text { winning van zand of klei. }\end{array}$ & $40 \mathrm{~cm}$ & $>40 \mathrm{~cm}$ & Ten minste 1 keer \\
\hline
\end{tabular}

\section{Ad 2}

Op de Bodemkaart van Nederland (Steur en Heijink, 1991) komen 24 legenda-eenheden voor gronden voor waarbij door zeer ingrijpende bewerkingen het bodemprofiel niet meer classificeerbaar is volgens de Bodemclassificatie van Nederland. Het betreft o.a. groeves, gronddepots en mijnstorthopen, maar ook herontgonnen petgatgebieden of andere terreinen die in het verleden verbeterd zijn voor landbouwkundig gebruik. In Tabel 4 worden achtereenvolgens de attribuutnaam waaronder de informatie in de database van de bodemkaart is opgeslagen, de bijbehorende legenda-informatie en de diepte en frequentie van de vergravingen omschreven. De "sterke" vergravingen, groeves en mijnstorten zijn vaak zeer herkenbaar in het landschap, waardoor ze op de kaart ook nauwkeurig ingetekend konden worden. Ook voor deze onderscheiding geldt dat het een momentopname betreft.

Tabel 4 Omschrijving legenda vergraven gronden Bodemkaart van Nederland 1:50.000 met een niet classificeerbaar bodemprofiel (attribuut SCHOP).

\begin{tabular}{|c|c|c|c|c|c|c|}
\hline $\begin{array}{l}\text { Attribuut- } \\
\text { /kolomnaam }\end{array}$ & $\begin{array}{l}\text { Legenda } \\
\text { symbool }\end{array}$ & $\begin{array}{l}\text { Legenda } \\
\text { tekst }\end{array}$ & Legenda omschrijving & $\begin{array}{l}\text { Diepte } \\
\text { min. }\end{array}$ & $\begin{array}{l}\text { Diepte } \\
\text { max. }\end{array}$ & Frequentie \\
\hline BODEM1 & & Ie VERWERK & $\begin{array}{l}\text { Sterk vergraven terrein met sterk } \\
\text { verstoord bodemprofiel, vaak met } \\
\text { vermenging van meerdere } \\
\text { grondsoorten. }\end{array}$ & $100 \mathrm{~cm}$ & $>100 \mathrm{~cm}$ & Ten minste 1 keer \\
\hline BODEM1 & & Ib AFGRAV & $\begin{array}{l}\text { Sterk afgegraven terrein met sterk } \\
\text { afwijkende hoogteligging ten opzichte } \\
\text { van de omgeving (bijv. zandwinning, } \\
\text { leemput). }\end{array}$ & $100 \mathrm{~cm}$ & $>100 \mathrm{~cm}$ & Ten minste 1 keer \\
\hline
\end{tabular}




\begin{tabular}{|c|c|c|c|c|c|c|}
\hline $\begin{array}{l}\text { Attribuut- } \\
\text { /kolomnaam }\end{array}$ & $\begin{array}{l}\text { Legenda } \\
\text { symbool }\end{array}$ & $\begin{array}{l}\text { Legenda } \\
\text { tekst }\end{array}$ & Legenda omschrijving & $\begin{array}{l}\text { Diepte } \\
\text { min. }\end{array}$ & $\begin{array}{l}\text { Diepte } \\
\text { max. }\end{array}$ & Frequentie \\
\hline BODEM1 & $\Upsilon$ & |a GROEVE & $\begin{array}{l}\text { Sterk afgegraven terrein in groeve } \\
\text { (bijv. zand-, grind-, kalkgroeve). }\end{array}$ & $100 \mathrm{~cm}$ & $>100 \mathrm{~cm}$ & Ten minste 1 keer \\
\hline BODEM1 & 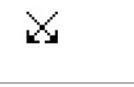 & Ij MYNSTRT & $\begin{array}{l}\text { Sterk opgehoogd terrein door } \\
\text { afvalmateriaal uit mijnbouw. }\end{array}$ & $100 \mathrm{~cm}$ & $>100 \mathrm{~cm}$ & Ten minste 1 keer \\
\hline BODEM1 & & AAK & Afgegraven kleigronden & $100 \mathrm{~cm}$ & $>100 \mathrm{~cm}$ & Ten minste 1 keer \\
\hline BODEM1 & & $\mathrm{AQ}$ & Met huisvuil opgehoogde gronden & $100 \mathrm{~cm}$ & $>100 \mathrm{~cm}$ & Ten minste 1 keer \\
\hline BODEM1 & & AGm9C & $\begin{array}{l}\text { Hollebollige, gemoerde } \\
\text { zeekleigronden; zware zavel en lichte } \\
\text { klei. }\end{array}$ & $100 \mathrm{~cm}$ & $>100 \mathrm{~cm}$ & Ten minste 1 keer \\
\hline BODEM1 & & AVo & Veen in ontginning & $100 \mathrm{~cm}$ & $>100 \mathrm{~cm}$ & Ten minste 1 keer \\
\hline BODEM1 & & AP & Petgaten & $100 \mathrm{~cm}$ & $>100 \mathrm{~cm}$ & Ten minste 1 keer \\
\hline BODEM1 & & AAP & Aangemaakte petgaten & $100 \mathrm{~cm}$ & $>100 \mathrm{~cm}$ & Ten minste 1 keer \\
\hline BODEM1 & & AEk9 & $\begin{array}{l}\text { Geëgaliseerde en verwerkte } \\
\text { zeekleigronden zonder veen binnen } \\
120 \mathrm{~cm} \text {; zware zavel en klei. }\end{array}$ & $100 \mathrm{~cm}$ & $>100 \mathrm{~cm}$ & Ten minste 1 keer \\
\hline BODEM1 & & AEm5 & $\begin{array}{l}\text { Geëgaliseerde en verwerkte } \\
\text { zeekleigronden met plaatselijk veen } \\
\text { binnen } 120 \mathrm{~cm} \text {; zavel. }\end{array}$ & $100 \mathrm{~cm}$ & $>100 \mathrm{~cm}$ & Ten minste 1 keer \\
\hline BODEM1 & & AEm8 & $\begin{array}{l}\text { Geëgaliseerde en verwerkte } \\
\text { zeekleigronden met plaatselijk veen } \\
\text { binnen } 120 \mathrm{~cm} \text {; klei. }\end{array}$ & $100 \mathrm{~cm}$ & $>100 \mathrm{~cm}$ & Ten minste 1 keer \\
\hline BODEM1 & & AEm9 & $\begin{array}{l}\text { Geëgaliseerde en verwerkte } \\
\text { zeekleigronden met plaatselijk veen } \\
\text { binnen } 120 \mathrm{~cm} \text {; zware zavel en lichte } \\
\text { klei. }\end{array}$ & $100 \mathrm{~cm}$ & $>100 \mathrm{~cm}$ & Ten minste 1 keer \\
\hline BODEM1 & & AEm9A & $\begin{array}{l}\text { Geëgaliseerde en verwerkte } \\
\text { zeekleigronden met plaatselijk veen } \\
\text { binnen } 120 \mathrm{~cm} \text { of met niet-gerijpte } \\
\text { ondergrond; zware zavel en lichte } \\
\text { klei. }\end{array}$ & $100 \mathrm{~cm}$ & $>100 \mathrm{~cm}$ & Ten minste 1 keer \\
\hline BODEM1 & & AEp6A & $\begin{array}{l}\text { Geëgaliseerde en verwerkte } \\
\text { zeekleigronden (eerd- en } \\
\text { vaaggronden met gerijpte } \\
\text { ondergrond); zavel en lichte klei, } \\
\text { kalkrijk. }\end{array}$ & $100 \mathrm{~cm}$ & $>100 \mathrm{~cm}$ & Ten minste 1 keer \\
\hline BODEM1 & & AEp7A & $\begin{array}{l}\text { Geëgaliseerde en verwerkte } \\
\text { zeekleigronden (eerd- en } \\
\text { vaaggronden met gerijpte } \\
\text { ondergrond); zware zavel en klei, } \\
\text { kalkrijk. }\end{array}$ & $100 \mathrm{~cm}$ & $>100 \mathrm{~cm}$ & Ten minste 1 keer \\
\hline BODEM1 & & $\mathrm{AWg}$ & Warmoezerijgronden (gerijpt) & $100 \mathrm{~cm}$ & $>100 \mathrm{~cm}$ & Ten minste 1 keer \\
\hline BODEM1 & & AWo & Warmoezerijgronden (ongerijpt) & $100 \mathrm{~cm}$ & $>100 \mathrm{~cm}$ & Ten minste 1 keer \\
\hline BODEM1 & & AWv & Warmoezerijgronden (veen) & $100 \mathrm{~cm}$ & $>100 \mathrm{~cm}$ & Ten minste 1 keer \\
\hline BODEM1 & & AVk & Veenafbraakgebied & $100 \mathrm{~cm}$ & $>100 \mathrm{~cm}$ & Ten minste 1 keer \\
\hline
\end{tabular}

\subsubsection{Gedetailleerde bodemkaarten}

Voor een groot deel van Nederland zijn gedetailleerde bodemkaarten beschikbaar. Alterra is de bronhouder van deze kaarten. Het merendeel van deze kaarten is als Geotiff beschikbaar en van de recentere kaarten (na 1980 à 1985) zijn GIS-bestanden voorhanden. De oudste kaarten dateren van 1942, de recentste kaarten zijn uit 2014. Voor deze kaarten is een uitgebreide veldinventarisatie uitgevoerd. Bij kaarten met schaal $1: 10000$ bedraagt de boringsdichtheid ca. 1 boring per ha en bij kaarten schaal $1: 250001$ à 2 boringen per 5 ha. De begrenzing en meta-informatie van deze detailkaarten is via het GIS van de Verstoringsbronnenkaart te raadplegen. Veel analoge kaarten, inclusief legenda, zijn ook ontsloten via het internet (https://library.wur.nl/cck/). Van elke kaart is een beperkte set aan meta-informatie beschikbaar (zie Tabel 5). 
Tabel 5 Overzicht meta-informatie bij detail bodemkaarten.

\begin{tabular}{ll} 
Attribuutnaam & Omschrijving \\
NAAM & Naam kartering \\
\hline DOEL & Ruilverkaveling, Boswachterij etc. \\
\hline AUTEUR & Naam van de auteur \\
\hline JAAR & Jaar van opname \\
\hline SCHAAL & Schaal, variërend van $1: 500$ tot $1: 25.000$ \\
\hline OPPERVLAKTE & Totale oppervlakte van de kartering \\
\hline RAPPORT & STIBOKA-, Staring Centrum-, of Alterra-rapport nr. \\
\hline BODEMKAART & Analoge of digitale kartering \\
\hline GT_KAART & Grondwatertrappenkaart aanwezig ja/nee \\
\hline BOORP_KAAR & Boorpuntenkaart aanwezig ja/nee \\
\hline BOORSTAAT & Boorstaten aanwezig ja/nee \\
\hline DoelKlass & Doel van de kartering \\
\hline BruikbaarA & Bruikbaarheid m.b.t. bodemverstoring* \\
\hline * Toegevoegd in het kader van Verstoringsbronnen Archeologie Nederland
\end{tabular}

De vraag is nu of deze kaarten bruikbare informatie verschaffen over verstoring van de bodemopbouw vanaf een diepte vanaf $30 \mathrm{~cm}-\mathrm{mv}$ en dieper. Bij het beoordelen of de informatie van detailkaarten bruikbaar is, spelen de volgende vragen:

1. Geeft de detailkaart informatie over verstoringen?

Sinds ongeveer 1965 wordt er bij de detailkarteringen gewerkt met een min of meer universele legenda, waarin ook de vergravingen worden onderscheiden (geëgaliseerd, vergraven, opgehoogd en afgegraven). In Tabel 6 worden de attributen en de bijbehorende legenda-eenheden met betrekking op bodemverstoringen weergegeven en beschreven. Op de oudere kaarten ontbreekt deze informatie vaak of maakt de informatie onderdeel uit van de legenda-eenheid (zoals op de bodemkaart van Boswachterij Sprielde uit 1962: code 1 tot 6 Holtpodzolgronden, diep gespit; code 7 Holtpodzolgronden ondiep gespit).

2. Wat is de betekenis van de informatie op de kaart voor de actuele situatie? Naast het jaar van opname (vermeld bij alle kaarten) kan de betekenis voor de actuele situatie gekoppeld worden aan het doel waarvoor de kaarten gemaakt zijn.

- Ruilverkaveling- en landinrichtingsprojecten. Bij de uitvoering van landinrichtingsprojecten zijn na de bodemkartering vaak kavel- en grondverbeteringswerken uitgevoerd. Dit ging gepaard met soms diepe grondbewerkingen. Deze detailkaarten geven dus alleen de situatie weer van voor de ruilverkaveling. De kans dat er daadwerkelijk ingrepen hebben plaatsgevonden, is afhankelijk van de oorspronkelijke verkaveling en van het landschap. In de veenweidegebieden zijn de bodemingrepen beperkter geweest dan in bijvoorbeeld de veenkoloniën of de WestNederlandse vaarpolders die geheel zijn omgeturnd naar rijpolders, waarbij veel vaarten zijn gedempt en wegen zijn aangelegd.

- Bosgebieden en boswachterijen. Voor dit soort gebieden kan worden aangenomen dat er na de kartering geen grootschalige ingrepen zijn uitgevoerd. Dus die informatie mag worden verondersteld als actueel.

- Nieuwe natuur of voor hermeandering van rivieren en beken. Het inrichten van nieuwe natuurgebieden gaat vaak gepaard met het weghalen van de nutriëntenrijke bovengrond. Bij aanpassingen van rivier- en beeklopen wordt lokaal ook gegraven en opgehoogd. 
Tabel 6 Omschrijving legenda vergraven gronden op detailbodemkaarten met een resp. nietclassificeerbaar (attribuut Kepr_lck) en een classificeerbaar bodemprofiel (attribuut Kepr_verg).

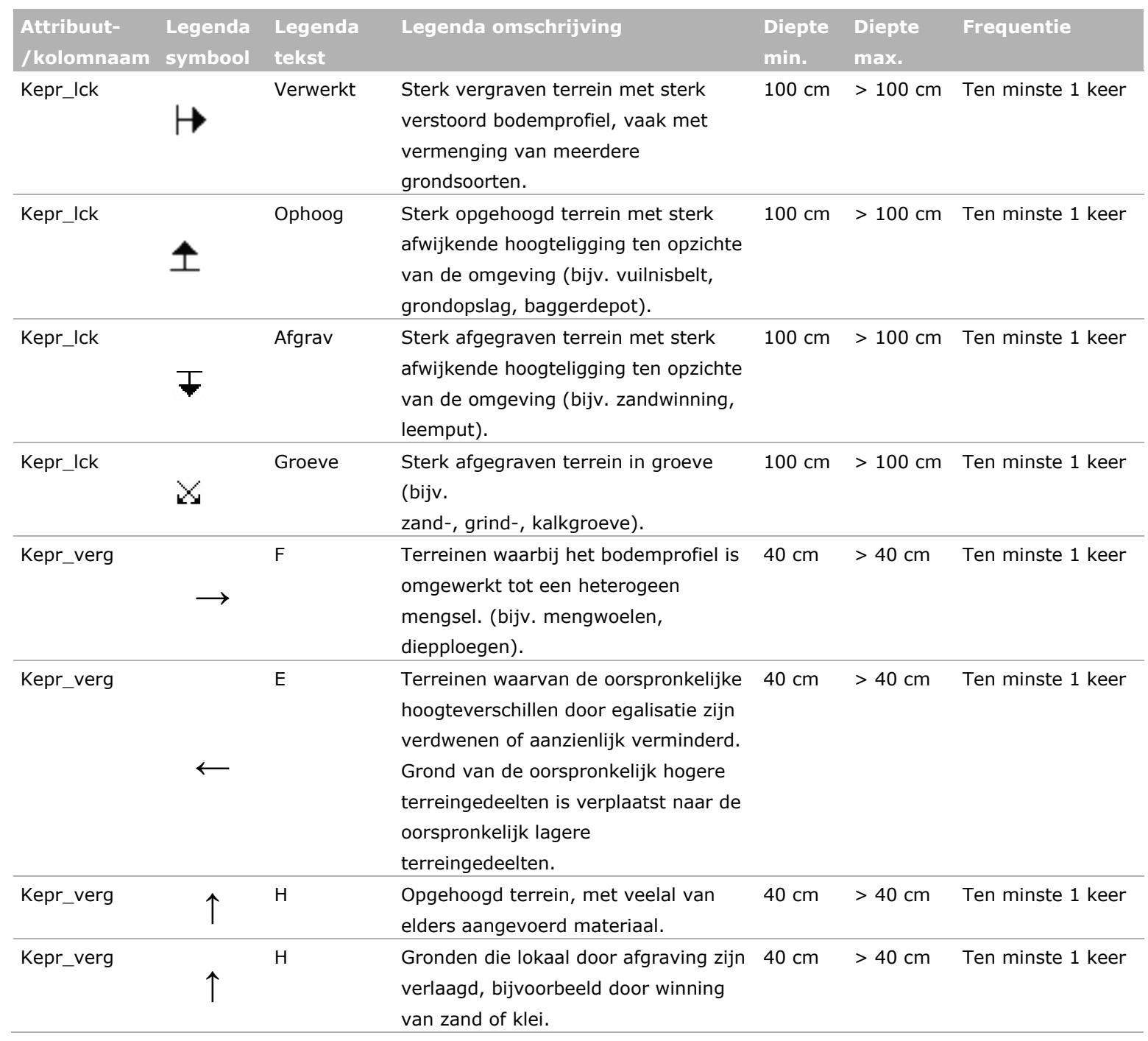

Om een antwoord te geven op de vraag of de bodeminformatie op de detailbodemkaarten nog relevant is voor bodemverstoring, worden de gegevens die detailkaarten over verstoringen bieden, ingedeeld naar actualiteit of compleetheid wat betreft informatie over bodemverstoring. De indeling is gerelateerd aan het doel van de kartering en aan de periode van opname. De indeling kent de volgende klassen (zie ook Figuur 1 en Tabel 7):

- Incompleet; dit geldt voor de karteringen die voor 1965 zijn uitgevoerd. Op de eerste kaarten werden verstoringen in de bodemopbouw niet altijd vastgelegd of werd er een project-afhankelijke onderscheiding gehanteerd. Tevens is de opname zo oud, dat er sindsdien waarschijnlijk allerlei ingrepen hebben plaatsgevonden. Ook recente karteringen in het kader van natuurherstel en hermeandering van waterlopen worden tot deze categorie gerekend, omdat er bij het uitvoeren van de plannen gebieden worden afgegraven en meanders worden gegraven.

- Compleet tot ...; karteringen ter voorbereiding van landinrichtingsprojecten zijn vaak een momentopname, omdat na de bodemkartering meestal ingrijpende cultuurtechnische ingrepen zijn worden uitgevoerd. De karteringen zijn naar ouderdom ingedeeld in categorieën van tien jaar.

- Compleet; de informatie over vergravingen in boswachterijen die na 1975 bij bodemkarteringen is verzameld, is hoogst waarschijnlijk compleet. 


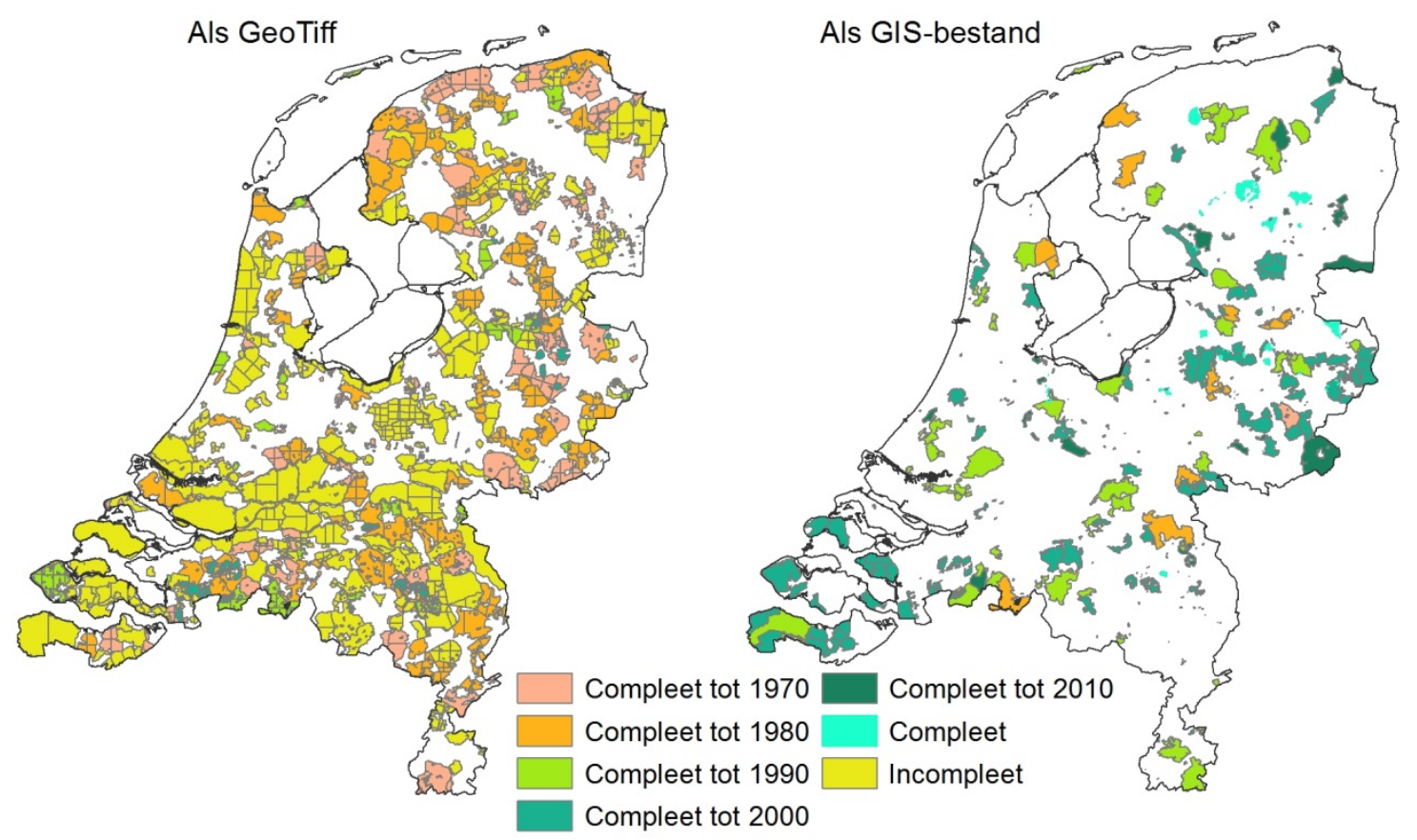

Figuur 1 Beschikbaarheid van informatie over vergravingen op gedetailleerde bodemkaarten.

Tabel 7 Oppervlakteoverzicht van de detailkaarten per periode.

\begin{tabular}{|c|c|c|c|c|c|c|c|}
\hline \multirow{2}{*}{$\begin{array}{l}\text { Periode } \\
1942 \text { - } 1959\end{array}$} & \multicolumn{3}{|c|}{ Oppervlakte (ha) detailkaarten } & \multirow{2}{*}{$\begin{array}{l}\text { Info } \\
\text { vergravingen } \\
\text { Project- } \\
\text { afhankelijk }\end{array}$} & \multicolumn{3}{|c|}{$\begin{array}{l}\text { Compleetheid afhankelijk van doel en } \\
\text { ouderdom van de karteringen }\end{array}$} \\
\hline & 685.236 & 491 & 685.726 & & Incompleet & Incompleet & N.v.t. \\
\hline $1960-1964$ & 304.783 & - & 304.783 & $\begin{array}{l}\text { Project- } \\
\text { afhankelijk }\end{array}$ & Incompleet & Incompleet & N.v.t. \\
\hline $1970-1979$ & 600.106 & 73.916 & 674.022 & $\mathrm{Ja}$ & Compleet tot 1980 & Compleet & N.v.t. \\
\hline $1980-1989$ & 116.356 & 197.131 & 313.487 & $\mathrm{Ja}$ & Compleet tot 1990 & Compleet & N.v.t. \\
\hline $1990-1999$ & 27.042 & 257.695 & 284.737 & $\mathrm{Ja}$ & Compleet tot 2000 & Compleet & Incompleet \\
\hline $2000-2014$ & - & 74.084 & 74.084 & $\mathrm{Ja}$ & Compleet tot 2010 & Compleet & Incompleet \\
\hline
\end{tabular}

\subsubsection{Landgebruikskaarten}

\subsubsection{CBS BBG-210}

Het CBS-bestand Bodemgebruik (BBG) bevat de geometrie van de begrenzingen van het bodemgebruik in Nederland. De kaart geeft inzicht in de verspreiding van verschillende vormen van ruimtegebruik in Nederland. Voorbeelden van het bodemgebruik zijn: verkeersterreinen, bebouwing, recreatieterreinen, natuurterreinen, binnenwater en buitenwater. Het BBG is een vectorbestand gebaseerd op TOP10vector en luchtfoto's waarmee het gebruik van de bodem wordt vastgesteld. Het jaar van opname van de luchtfoto's, ruwweg in de periode april-september, bepaalt het jaar van de inventarisatie. Objecten die op het tijdstip van de foto-opname niet aanwezig zijn, worden niet in het BBG opgenomen. Voor het inventarisatiejaar van het BBG worden de recentste TOP10vectorbestanden gebruikt. De geometrie van het BBG is, vanaf de opname 2000, volledig geënt op de basisgeometrie van het Top10Vector-bestand. Het bodemgebruik in het BBG is geclassificeerd in 38 categorieën en 9 hoofdgroepen. In de vergraven-grondenkaart zijn 13 hoofdgroepen/categorieën uit het BBG opgenomen (zie Tabel 8). Deze zijn vertaald naar 9 typen op de vergraven-grondenkaart. 
Tabel 8 Hoofdgroepen/categorieën uit het BBG die kunnen aangemerkt als potentieel vergraven gronden. Diepte en frequentie zijn niet bekend.

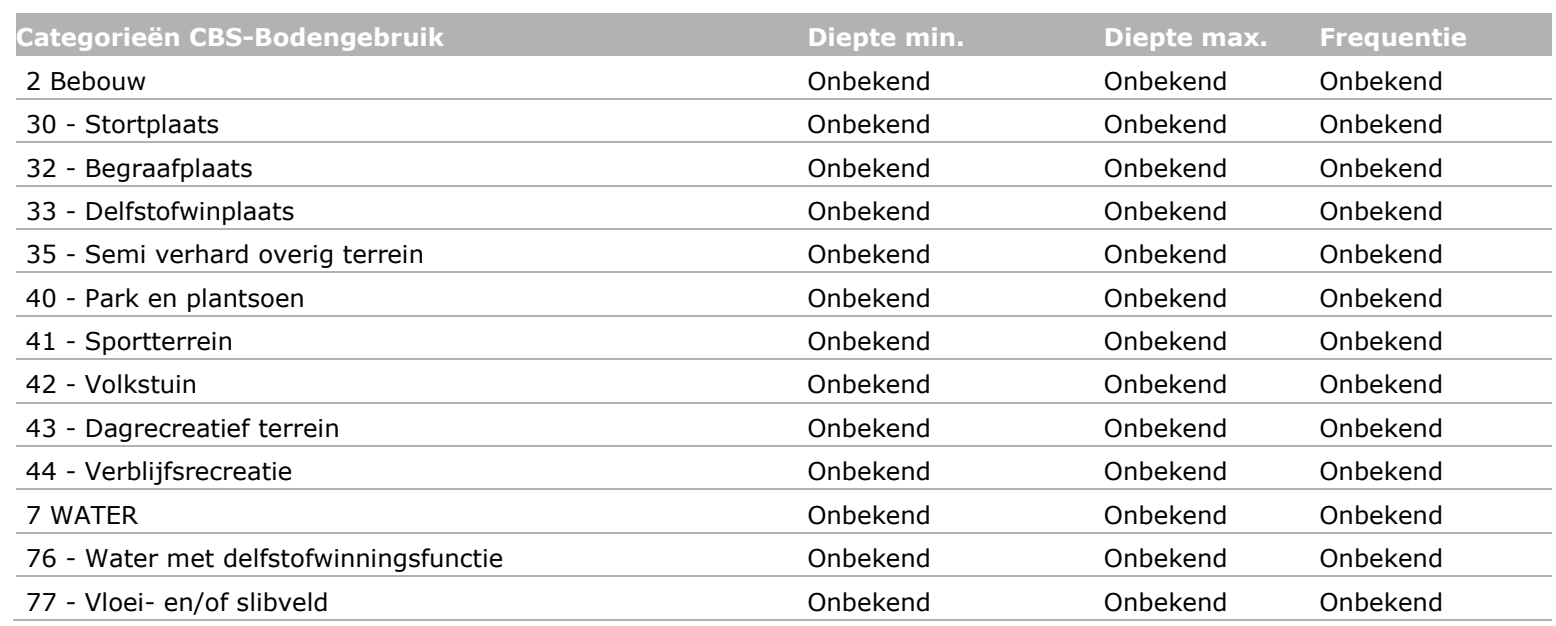

\subsubsection{Basisregistratie Percelen (BRP)}

Elk perceel in Nederland dat in agrarisch gebruik is, wordt geregistreerd via de 'Basisregistratie Percelen' (BRP). De inwinning vindt plaats door de Rijksdienst voor Ondernemend Nederland (RVO) van het ministerie van Economische Zaken, waarbij de volgende definitie wordt gehanteerd:

'Een gewasperceel is een aaneengesloten stuk landbouwgrond in Nederland. Een gewasperceel is in gebruik bij één landbouwer, heeft één gebruikstitel (bijvoorbeeld eigendom, pacht, erfpacht) en wordt beteeld met één enkel gewas. Een gewasperceel ligt altijd binnen een topografisch perceel. Een topografisch perceel kan ook bestaan uit meerdere gewaspercelen die bij een of meerdere landbouwers in gebruik zijn.' (www.RVO.nl)

De perceelgegevens worden gebruikt voor de uitvoering van het Mestbeleid (het stelsel van gebruiksnormen en derogatie), het Gemeenschappelijk landbouwbeleid (subsidies en bedrijfstoeslag) en voor de subsidieregelingen voor agrarisch natuurbeheer (www.rvo.nl, februari 2014).

Het BRP is beschikbaar als GIS-bestand (vector), waarbij voor elk perceel een gewascode beschikbaar is. Het BRP van 2012 bevat 179 unieke gewascodes, waaruit een grondgebruiker kan kiezen bij het registeren van zijn percelen. Deze gewascodes zijn over de jaren heen gewijzigd, waardoor het onderling vergelijken van de BRP gegevens niet een-op-een mogelijk is, maar een vertaalslag in vergelijkbare codes vraagt. De BRP is voor elk kalenderjaar beschikbaar vanaf 2006. Tabel 9 geeft een overzicht van relevante gewascategorieën en een inschatting van de bewerkingsdiepte aan de hand van het rapport van Reuler (2014). Bij een aantal categorieën bedraagt de bewerkingsdiepte meer dan $30 \mathrm{~cm}$.

Tabel 9 Gewascategorieën BRP samengevat naar bodembewerkingsdiepte.

\begin{tabular}{llll} 
Gewascategorie & Diepte min. & Diepte max. & Frequentie \\
Grasland & 30 & 30 & Incidenteel \\
\hline Tuinbouw regulier & 30 & 30 & Jaarlijks \\
\hline Sierteelt & 30 & 30 & Jaarlijks \\
\hline Akkerbouw regulier & 30 & 30 & Jaarlijks \\
\hline Mais & 30 & 40 & Jaarlijks \\
\hline Bloembollen & 30 & 40 & Jaarlijks \\
\hline Miscanthus & 40 & 40 & Bij aanleg \\
\hline Boomkwekerij struiken & 40 & 40 & Bij aanleg en rooien \\
\hline Boomkwekerij laanbomen & 60 & 60 & Bij aanleg en rooien \\
\hline Asperges & 60 & 60 & Bij aanleg \\
\hline Boomgaard & 60 & 60 & Bij aanleg en rooien
\end{tabular}




\subsubsection{Landelijk Grondgebruik Nederland (LGN)}

Sinds 1986 vervaardigt Alterra Wageningen UR het gridbestand 'Landelijk Grondgebruik Nederland', afgekort LGN, met een frequentie van 3-5 jaar. Vanaf 1986 tot 2013 zijn 7 versies uitgekomen (Tabel 10), elk met een resolutie van $25 \times 25 \mathrm{~m}$ (Hazeu et al. 2005).

Tabel 10 Opnamejaar LGN-bestanden.

\begin{tabular}{ll} 
Versie & Opnamejaar satellietbeelden \\
\hline LGN7 & 2012 \\
\hline LGN6 & 2007,2008 \\
\hline LGN5 & 2003,2004 \\
\hline LGN4 & 1999,2000 \\
\hline LGN3 & 1995,1997 \\
\hline LGN2 & $1990,1992,1994$ \\
\hline LGN1 & $1984,1986,1987$ \\
\hline
\end{tabular}

Het LGN is beschikbaar voor geheel Nederland als een GIS-bestand in een grid-formaat, met een resolutie van $25 \times 25 \mathrm{~m}$. De classificatie van het landgebruik is grotendeels constant gebleven over de verschillende jaargangen van het LGN. Door verbeterde inwinningtechnieken en wensen van gebruikers is er in de loop der jaren wel een aantal landgebruiksklassen toegevoegd. Zo is er een aantal codes voor natuur en boomteelt toegevoegd:

- boomkwekerijen (klasse 61)

- fruitkwekerijen (klasse 62)

- gras in secundair bebouwd gebied (klasse 28)

De boomkwekerijen behoorden in de versies LGN1 tot en met LGN5 tot de klasse 'overige landbouwgewassen' (Hazeu et al, 2010). In LGN6 en LGN7 worden de boomkwekerijen wel apart onderscheiden. Deze veranderingen zijn van belang voor het in kaart brengen van bodemverstoring, omdat boomkwekerijen een grotere bewerkingsdiepte kunnen hebben dan de 'overige' landbouwgewassen (Reuler et al. 2014).

De vergelijkbaarheid van het LGN over de verschillende versies is beperkt, omdat de methode voor het samenstellen van de bestanden met elke versie verder ontwikkeld werd en daarmee veranderd is. LGN1 en LGN2 waren nog experimentele bestanden met beperkte nauwkeurigheid en nog duidelijke tekortkomingen. In het LGN3-bestand zijn deze tekortkomingen grotendeels opgelost en met LGN3plus is de bruikbaarheid van het bestand voor toepassingen op het gebied van natuur en ecologie sterk verbeterd (Hazeu et al. 2005). In LGN4 is voor het eerst een koppeling gemaakt met de digitale topografische kaart Top10vector van het Kadaster, maar dan alleen voor de landbouwpercelen (Hazeu, et al. 2005).

De geometrie en thematiek op hoofdklassen is vanaf LGN6 volledig gebaseerd op het Top10vectorbestand (versie 2006). Verder is voor het stedelijk gebied aansluiting gezocht met het bestand 'Bestand Bodem Gebruik (BBG2003)' van het Centraal Bureau voor de Statistiek (CBS) en het bestand 'Bebouwd Gebied (BG2003)' van het ministerie van VROM. Daarnaast zijn de natuurlijke graslanden, rietmoerassen en duinen uit het bestand 'BasisKaart Natuur (BKN2006)' van Alterra overgenomen. De bossen en heide zijn opnieuw geclassificeerd op basis van satellietbeelden uit 2007/2008. Tot slot zijn er enkele landgebruiksklassen verdwenen en bijgekomen (Hazeu et al. 2010).

De vergelijking van de statistieken van LGN6 met voorgaande versies is moeilijker als gevolg van aanpassingen in de methodiek. Een afname en/of toename aan arealen per landgebruiksklasse tussen LGN5 en LGN6 is in veel gevallen niet het gevolg van werkelijke landgebruiksveranderingen, maar veelal het gevolg van methodologische veranderingen (Hazeu et al. 2010). De tussenbestanden LGN5_6 en LGN6_5 komen tegemoet aan dit probleem. Tabel 11 geeft een overzicht van de LGN7landgebruiksklassen en een inschatting van de bewerkingsdiepte aan de hand van het rapport van Reuler (2014). 
Tabel 11 LGN7-Landgebruiksklassen met een agrarisch gebruik met bijbehorende bewerkingsdiepte en frequentie.

\begin{tabular}{lccc} 
OMSCHRTJING & Diepte min. & Diepte max. & frequentie \\
1 - Agrarisch gras & 30 & 30 & Incidenteel \\
\hline 2 - Mais & 30 & 40 & Jaarlijks \\
\hline 3 - Aardappelen & 30 & 30 & Jaarlijks \\
\hline 4 - Bieten & 30 & 30 & Jaarlijks \\
\hline 5 - Granen & 30 & 30 & Jaarlijks \\
\hline 6 - Overige gewassen (incl. braak) & 30 & 30 & Jaarlijks \\
\hline 8 - Glastuinbouw & nvt & & Bij aanleg en rooien \\
\hline 9 - Boomgaarden & 60 & 60 & Jaarlijks \\
\hline 10 - Bloembollen & 30 & 40 & Bij aanleg en rooien \\
\hline 61 - Boomkwekerijen & 60 & 60 & Bij aanleg en rooien \\
\hline 62 - Fruitkwekerijen & 60 & 60 &
\end{tabular}

\subsubsection{Kaartenbestanden met locatie-specifieke ingrepen}

\subsubsection{Provinciale registraties}

Tabel 12 geeft een overzicht van de provinciale registraties die betrekking hebben op bodemverstoringen. In totaal zijn er 46 registraties bekend bij 11 provincies. Flevoland beschikt niet over registraties van bodemverstoringen.

De meeste provincies beschikken over een of meerdere overzichten van locaties van delfstofwinningen en stortplaatsen. De andere typen registraties, zoals gronddepots of bodemsaneringslocaties, komen maar bij enkele provincies voor. Daar waar in het overzicht meerdere registraties per type zijn aangegeven, gaat het in de meeste gevallen om verschillen in de status van het type verstoring. Bijvoorbeeld actuele delfstofwinningslocaties versus afgesloten winningen.

Van de registraties in Tabel 12 kan vrijwel zeker worden aangenomen dat bodemverstoring heeft plaatsgevonden, maar de mate waarin, is in de meeste gevallen niet uit de metadata van de registraties af te leiden.

Tabel 12 Registraties bodemverstoring bij de provincies.




Niet opgenomen in het overzicht van registraties bodemverstoring zijn bestanden van dijken en waterkeringen en provinciale cultuurhistorische inventarisaties. Deze registraties behoren tot de categorie van cultuurhistorisch en archeologisch (potentieel) waardevolle gebieden.

De meeste provincies hebben de gegevens ontsloten via het Provinciaal Georegister, zodat de informatie direct beschikbaar is voor gebruik. Provincie Zeeland heeft een deel van de informatie ontsloten via het Provinciaal Georegister en een deel via een eigen portaal. De gegevens van ZuidHolland zijn beschikbaar via het eigen provinciaal portaal. De provinciale gegevens worden door de gemeenten gebruikt in gemeentelijke databases die op de bodem betrekking hebben.

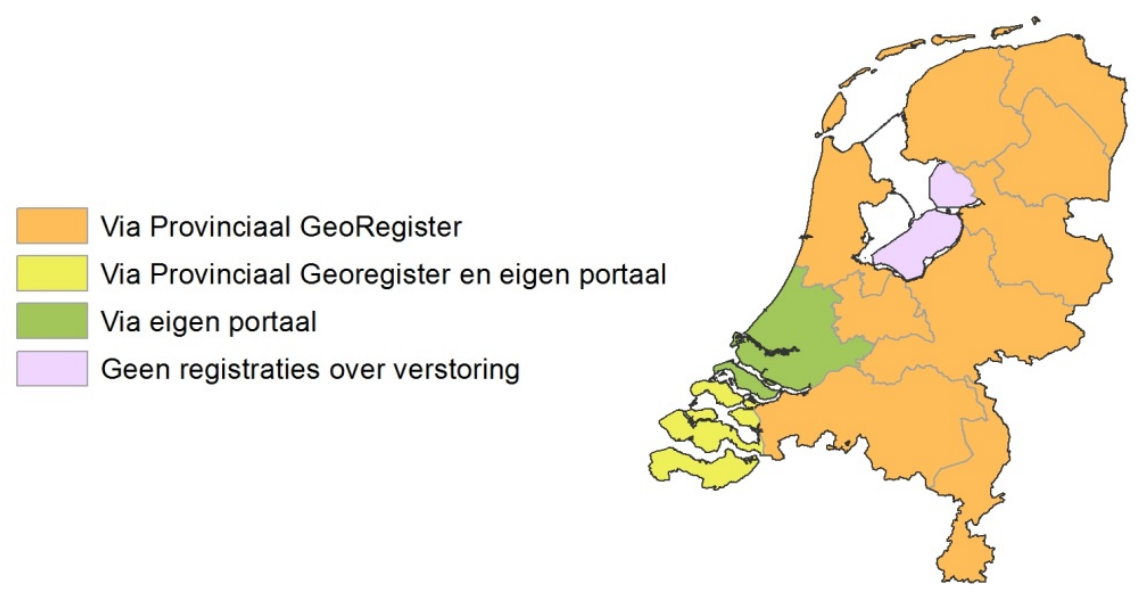

Figuur 2 Ontsluiting van de provinciale gegevens over bodemverstoring.

De provincie Drenthe heeft naast haar eigen registraties van delfstofwinningen en stortplaatsen, de vergraven en geëgaliseerde gronden van de Bodemkaart van Nederland 1:50.000 en de Vergraven grondenkaart (Brouwer en Van de Werff, 2012) ontsloten. De provincie Drenthe geeft aan zelf niet te beschikken over betrouwbare (overzichts)kaarten die inzicht geven in ontgronde gebieden en gebieden die op andere wijzen zo diep verstoord zijn dat zij geen archeologische (rest)waarde meer hebben. Wel is bij de afdeling Vergunningen, Toezicht en Handhaving (VTH), die zich met ontgrondingsvergunningen bezig houdt, een stippenkaart (pdf en jpeg) voorhanden met ontgrondingsvergunningen afgegeven in de periode 1959-2009. Deze kaart wordt intern aangeduid als de 'Roodnat'-kaart. De stippen zijn geplaatst op de betreffende kadastrale percelen. Deze kaart verschaft een globale indicatie, maar is niet voorzien van een codering die een ingang biedt tot het analoge archief (archief provinciehuis, provinciaal archief en mogelijk Rijksarchief). Daarnaast zijn de kadastrale aanduidingen door omnummeringen niet altijd meer actueel en ontbreekt de exacte begrenzing van het gebied waarvoor de ontgrondingsvergunning is afgegeven. Het terrein waarvoor de ontgrondingsvergunning is afgegeven, komt regelmatig niet overeen met het vervolgens daadwerkelijk ontgronde gebied.

De provincie Drenthe waarschuwt ervoor dat ontgronde percelen niet altijd zo diep ontgrond zijn dat het terrein archeologisch waardeloos geworden is, bijvoorbeeld bij turfwinning waarbij de pleistocene ondergrond niet geraakt is. Een vergelijkbare opmerking werd geuit door de provincie Noord-Holland: de informatie mag beslist niet gebruikt worden om grootschalig terreinen 'archeologisch vrij te geven'.

\subsubsection{Registraties Waterschappen}

Er is slechts bij een beperkt aantal waterschappen informatie over bodemverstoring beschikbaar en voor zover er informatie beschikbaar is, is dat niet via internet ontsloten. Hoogheemraadschap van Rijnland en de waterschappen Aa en Maas, De Dommel, Rivierenland en Rijn en IJssel hebben aangegeven te beschikken over informatie over ingrepen, zoals herstelwerkzaamheden aan beken, baggerprojecten en aanleg retentiegebieden. 
Wetterskyp Fryslân en Hunze en Aa's zijn bezig met een inventarisatie van ingrepen en met het samenstellen van een overzicht van ingrepen, in hoeverre ook gekeken wordt naar historische ingrepen is niet bekend. Bijna alle waterschappen geven op hun websites informatie over projecten die thans in uitvoering zijn. In welke mate dit ook in een GIS-bestand wordt vastgelegd, is niet bekend.

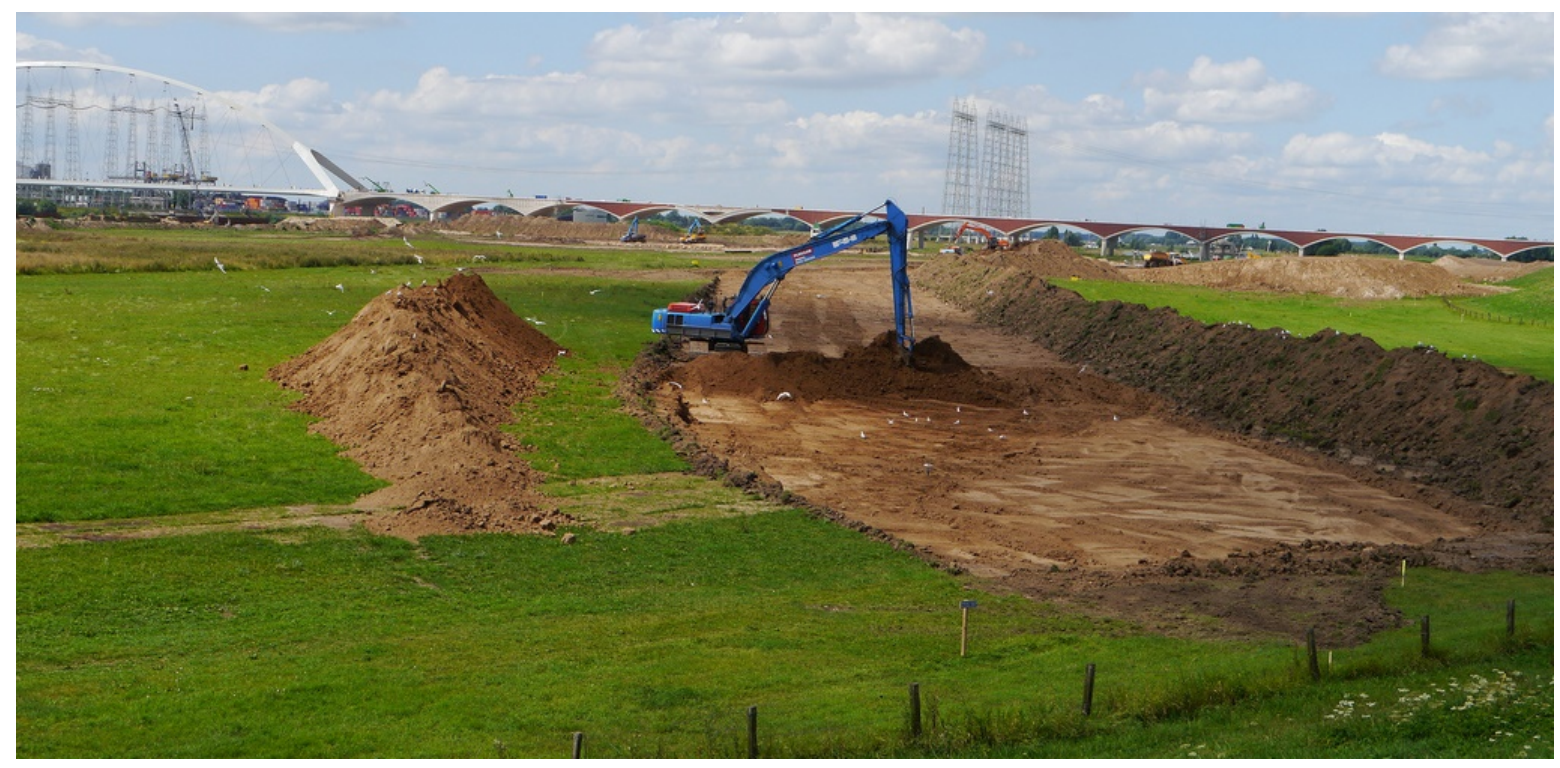

Figuur 3 Bodemverstoring in de Waaluiterwaarden bij Nijmegen in het kader van Ruimte voor de Rivier.

\subsubsection{Registratie Rijkswaterstaat}

Bij het vervullen van zijn taken hebben veel projecten van Rijkswaterstaat invloed op de bodemopbouw. Op verschillende fronten is Rijkswaterstaat betrokken bij projecten, zoals:

- Beheer en onderhoud van de 'primaire waterkeringen'. Zo worden binnen het programma Ruimte voor de Rivier allerlei projecten uitgevoerd om de waterveiligheid langs de grote rivieren te waarborgen (Figuur 3).

- Verbeteren van de bereikbaarheid door aanleg, beheer en onderhoud van het hoofdwegennet in ons land.

- Het beheer van Natura 2000-gebieden in gezamenlijkheid met provincies.

Rijkswaterstaat beschikt nog niet over een compleet overzicht met gebieden waar door ingrepen bodemverstoringen zijn opgetreden. Er is wel een proces opgestart om zo'n overzicht samen te stellen.

\subsubsection{Registratie Gasunie}

De N.V. Nederlandse Gasunie beheert een uitgebreid netwerk met gastransportleidingen in Nederland en zorgt voor de aanwezigheid van voldoende transportcapaciteit. In Nederland ligt meer dan $5000 \mathrm{~km}$ hoofdgastransportleiding (Figuur 4). Bij de aanleg van hooftransportleidingen wordt de bodem in een 25 à 50 brede strook beïnvloed. De Gasunie beschikt over een GIS-bestand met de ligging van de tracés van de hoofdtransportleidingen. Hiervan is echter geen openbare metainformatie beschikbaar. 


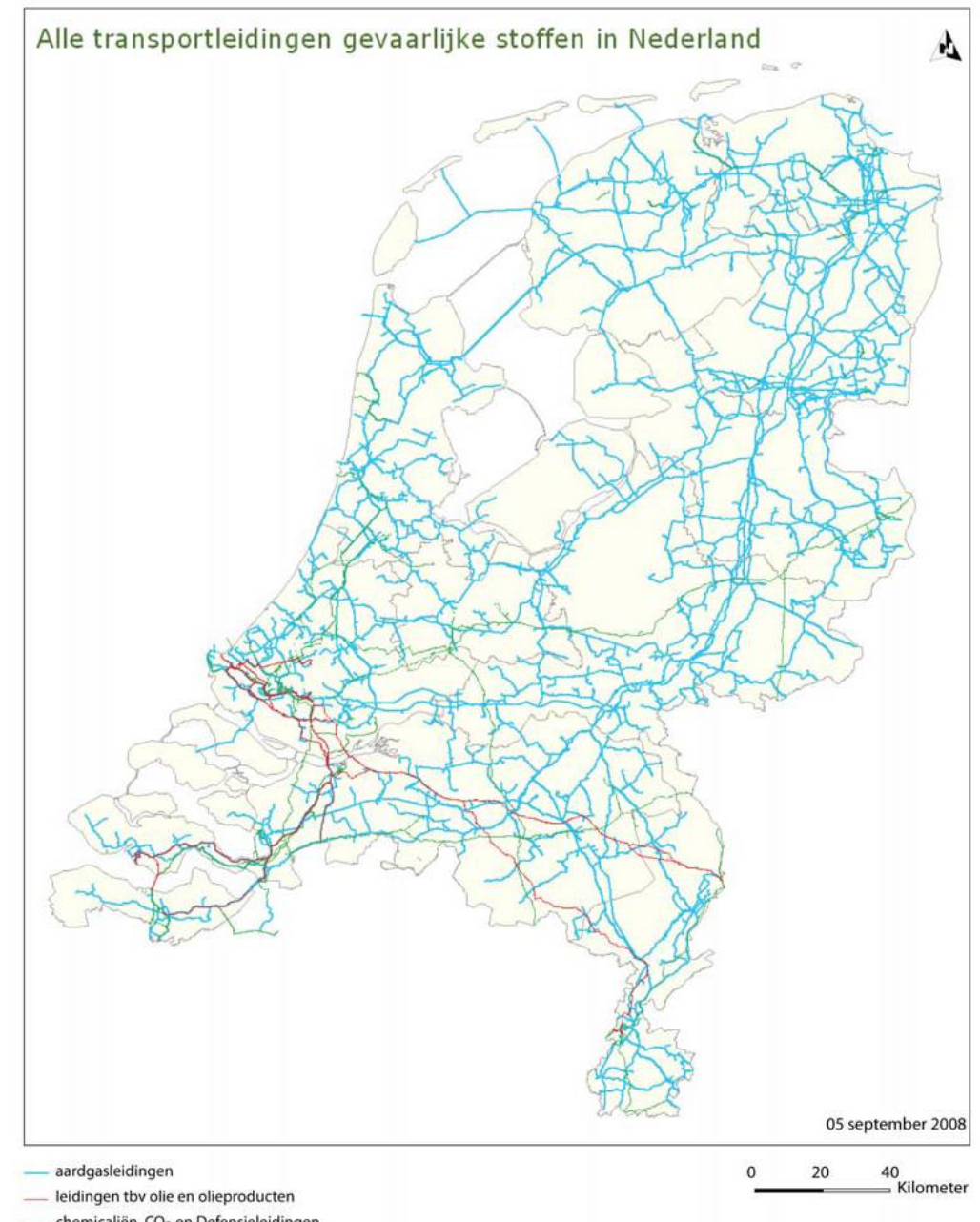

Figuur 4 Ondergrondse transportleidingen in Nederland (bron: www.buizenzone.nl). 


\section{$4 \quad$ Conclusies en aanbevelingen}

Dagelijks zijn er in Nederland veel graafactiviteiten, deels in opdracht van particulieren, maar ook vaak in opdracht van de gemeentelijke, provinciale en landelijke overheid en waterschappen. Uit deze inventarisatie blijkt dat:

- er geen complete overzichten zijn met gebieden waar bodemingrepen zijn of worden uitgevoerd;

- de provincies over registraties beschikken met locaties van gronddepots en stortplaatsen en gebieden die ontgrond zijn;

- er slechts enkele waterschappen zijn met registraties van cultuurtechnische ingrepen waarvoor zij zelf opdracht hebben gegeven;

- bodemkaarten onderscheid maken in vergraven en niet-vergraven gronden, maar dat deze kaarten vanwege de eenmalige momentopname toch geen actueel beeld geven;

- gedetailleerde bodemkaarten vaak zijn gemaakt ten behoeve van de voorbereiding van herinrichtingsprojecten. Waarna bij de realisatie van de herinrichting cultuurtechnische werken zijn uitgevoerd, met bodemverstoring tot gevolg.

Elke gemeente in Nederland heeft een wettelijke zorgplicht voor archeologie. Bij het plannen van graafactiviteiten dient de 'gravende' partij in overeenstemming met de gemeentelijke verordening een omgevingsvergunning aan te vragen. Voor kleinere ontgrondingen (veelal $<10000 \mathrm{~m}^{3}$ ) en bodemverstoringen door de reguliere landbouw en ten behoeve van natuurontwikkeling is veelal (bijv. in de provincie Gelderland) geen vergunning nodig, maar geldt wel een meldingsplicht. Aanbevolen wordt om de gemelde bodemverstoringen te registreren en in een GIS-bestand vast te leggen. Dit kan bijvoorbeeld door de aanvrager via een applicatie de locatie van het te bewerken perceel te laten invoeren (op gelijke wijze als bij de registratie van gewaspercelen in de basisregistratie percelen BRP). Voor grotere ontgrondingen (veelal $>10000 \mathrm{~m}^{3}$ ) is wel een vergunning vereist. Rijkswaterstaat verstrekt de vergunning voor ontgrondingen langs de Rijkswateren en de provincies doen dat voor de rest van Nederland. Aanbevolen wordt om ook deze ingrepen centraal te registreren. Bij het uitvoeren van werkzaamheden aan kabels en leidingen geldt al een centraal geregelde meldingsplicht en registratie in overeenstemming met de Wet Informatie-uitwisseling Ondergrondse Netten (WION). 


\section{Literatuur}

Bakker, H. de en J. Schelling, 1989. Systeem voor bodemclassificatie voor Nederland. De hogere niveaus. Wageningen. Pudoc.

Brouwer, F. en M.M. van der Werff, 2012. Vergraven gronden. Inventarisatie van 'diepe' grondbewerkingen, ophogingen en afgravingen. Alterra Wageningen UR, rapport 2336.

Hazeu, G.W., 2005. Landelijk Grondgebruiksbestand Nederland (LGN5). Vervaardiging, nauwkeurigheid en gebruik. Alterra Wageningen UR, rapport1213.

Hazeu, G.W., Schuiling, C., Dorland, G.J., Oldengarm, J. \& H.A. Gijsbertse, 2010. Landelijk Grondgebruiksbestand Nederland versie 6 (LGN6). Vervaardiging, nauwkeurigheid en gebruik. Alterra Wageningen UR, rapport 2012.

Hazeu, G.W., C. Schuiling, G.J. Dorland, G.J. Roerink, H.S.D. Naeff en R.A. Smidt, 2014. Landelijk Grondgebruiksbestand Nederland, versie 7 (LGN7). Vervaardiging, nauwkeurigheid en gebruik. Alterra Wageningen UR, rapport 2548.

Maas, G.J., W. Niuwenhuizen en M. Knotters, 2014. Voorstudie nadere uitwerking verstoringskaart archeologie Nederland. Alterra Wageningen UR. Interne Alterra-notitie.

Marsman, B.A. en J.J. de Gruijter, 1982. Kwaliteit van bodemkaarten; een vergelijking van karteringsmethoden in een zandgebied. Stichting voor Bodemkartering. Wageningen. Rapport 1714.

Massop, H.Th.L., C. Schuiling, 2014. Update landelijke buisdrainagekaart op basis van de landbouwmeitellingen van 2012. Wageningen, Alterra Wageningen UR, rapport 2700.

Reuler H. van, G.D. Vermeulen, J. Spruijt, D.J.M. van Balen, M.P.M. Derkx, G. Heijerman, A.H.M.C. Baltissen en J.J. de Haan, 2014. Inventarisatie van reguliere teelthandelingen in de landbouw in Nederland, de invloed ervan op de bodem in verband met de consequenties voor de archeologische resten. Wageningen, Praktijkonderzoek Plant \& Omgeving.

Steur, G.G.L. en W. Heijink, 1991. Bodemkaart van Nederland, schaal 1 : 50 000. Algemene begrippen en indelingen. Staring Centrum, Wageningen.

\section{Internet}

Bibliotheek Wageningen UR:

Nationaal Georegister:

Provinciaal Georegister:

Publieke diensten op de kaart (PDOK):

Wet Informatie-uitwisseling

Ondergrondse Netten (WION):

Meta-data standaard: https://library.wur.nl/cck/

nationaalgeoregister. $\mathrm{nl} /$

https://www.provinciaalgeoregister.nl/

http://pdokviewer.pdok.nl/

http://wetten.overheid.nl/

http://www.geonovum.nl/wegwijzer/standaarden/nederlandsmetadataprofiel-op-iso-19115-geografie-131 


\section{Bijlage 1 Leveringsverzoek}

Geachte heer/mevrouw...,

Betreft: Verstoringsbronnenkaart archeologie van Nederland

In deze brief vragen we om uw medewerking voor het leveren van informatie.

De Rijksdienst voor het Cultureel Erfgoed (RCE - onderdeel van het Ministerie van Onderwijs, Cultuur en Wetenschap) staat voor de bescherming van het Nederlandse erfgoed van nationaal belang, boven en onder de grond en onder water. Op dit moment voert de RCE, in het kader van het programma Kenniskaart Archeologie, het project Verstoringen in Kaart uit. Doel van het programma Kenniskaart is een betere afweging van de archeologische belangen binnen de ruimtelijke ordening. Dit moet onder meer resulteren in doelmatiger archeologisch onderzoek en het voorkomen van onnodig verstrekkende verplichtingen. Verstoringen in Kaart draagt bij aan deze effectievere archeologie door 'gereedschap' ter beschikking te stellen dat voorkomt dat onnodig archeologisch onderzoek op verstoorde bodems wordt uitgevoerd. Een van de gereedschappen is de RCE Verstoringbronnenkaart archeologie van Nederland.

RCE heeft aan Alterra Wageningen-UR de opdracht verleend om een overzicht samen te stellen van alle beschikbare kaarten met informatie over verstoringen van de bodem. Deze Verstoringsbronnenkaart zal als eerste ingang dienen bij de dataverzameling ten behoeve van Verstoringskanskaarten op lokaal niveau en vormt daarmee een handig gereedschap voor potentiële gebruikers, zoals gemeenten, adviseurs en grondeigenaren.

Wij doen een beroep op de medewerking van u en uw organisatie bij het samenstellen van dit overzicht van informatie over de verstoring van de bodem van Nederland. Wij hebben u aangeschreven, omdat wij verwachten dat binnen uw organisatie bodemkundige ingrepen en landschappelijke ingrepen met een effect op de bodem worden geregistreerd en/of vastgelegd in digitale vorm. Is dat het geval, dan bent $u$ bronhouder van informatie over bodemverstoringen en willen wij graag deze informatie opnemen in het overzicht dat wij aan het maken zijn.

\section{Concrete vraag:}

Voor een succesvolle inventarisatie van databases van vergraven gronden in Nederland verzoeken wij u de meta-informatie over de bestanden in uw beheer aan ons ter beschikking te stellen. Dit kunt u doen door het formulier in de bijlage zo compleet mogelijk in te vullen en terug te sturen aan een van de onderstaande Alterra-contactpersonen. De gevraagde metadata komen sterk overeen met de ISO-standaard voor meta-informatie (ISO 19115). Voor een toelichting op de velden die ingevuld dienen te worden, kunt u hoofdstuk 5 uit de meegeleverde pdf-file raadplegen. Indien uw GIS-bestand reeds volgens deze ISO-standaard is voorzien van meta-informatie kunt u hiervan ook een exportfile aan ons leveren, inclusief een geprinte versie.

Als binnen uw organisatie deze vraag beter door een andere persoon behandeld kan worden, wilt u deze mail/brief dan doorsturen of ons hiervan op de hoogte stellen? Mochten er nog vragen zijn of onduidelijkheden, dan kunt u ook contact opnemen met onderstaande contactpersonen.

Uw contactpersonen bij Alterra zijn:

Fokke Brouwer

tel: 0317486521

fokke.brouwer@wur.nl
Nanny Heidema

tel: 0317486487

nanny.heidema@wur.nl

Ik dank u voor uw medewerking.

Met vriendelijke groet,

Michel Lascaris

Projectleider RCE Verstoringen in Kaart

Rijksdienst voor het Cultureel Erfgoed

Smallepad 53811 MG Amersfoort

Tel: 0334217414

M.lascaris@cultureelerfgoed.nl 


\section{Bijlage 2 Reacties}

\begin{tabular}{|c|c|}
\hline Instantie & Reactie \\
\hline De Grondbank & geen reactie ontvangen \\
\hline Dienst Rijkswaterstaat & informatie wordt later opgeleverd \\
\hline N.V. Nederlandse Gasunie & geen metadata beschikbaar \\
\hline Provincie Friesland & geen reactie ontvangen \\
\hline Provincie Groningen & geen reactie ontvangen \\
\hline Provincie Drenthe & informatie ontsloten via provinciaal Geoportaal \\
\hline Provincie Overijssel & geen reactie ontvangen \\
\hline Provincie Gelderland & informatie ontsloten via provinciaal Geoportaal \\
\hline Provincie Flevoland & geen informatie beschikbaar \\
\hline Provincie Noord Holland & informatie ontsloten via provinciaal Geoportaal \\
\hline Provincie Zuid Holland & informatie onsloten via NGR \\
\hline Provincie Utrecht & informatie ontsloten via provinciaal Geoportaal \\
\hline Provincie Zeeland & metadata-file $(\mathrm{xml})$ opgestuurd \\
\hline Provincie Brabant & informatie ontsloten via provinciaal Geoportaal \\
\hline Provincie Limburg & informatie ontsloten via provinciaal Geoportaal \\
\hline Wetterskip Fryslan & informatie wordt later opgeleverd \\
\hline Waterschap Noorderzijlvest & geen reactie ontvangen \\
\hline Waterschap Reest en Wieden & geen reactie ontvangen \\
\hline Waterschap Hunze en Aa's & informatie wordt later opgeleverd \\
\hline Waterschap Vechtstromen & geen informatie beschikbaar \\
\hline Waterschap Groot Salland & geen reactie ontvangen \\
\hline Waterschap Zuiderzeeland & geen reactie ontvangen \\
\hline Waterschap Rijn en Ijssel & metadata-file $(x \mathrm{ml})$ opgestuurd \\
\hline Waterschap Vallei en Veluwe & geen informatie beschikbaar \\
\hline HH Hollands Noorderkwartier & geen reactie ontvangen \\
\hline Waterschap Amstel, Gooi en Vecht & geen reactie ontvangen \\
\hline $\mathrm{HH}$ van Rijnland & geen metadata beschikbaar \\
\hline HH De Stichtse Rijnlanden & geen informatie beschikbaar \\
\hline Waterschap Rivierenland & informatie ontsloten via NGR \\
\hline HH van Delfland & geen informatie beschikbaar \\
\hline HH van Schieland en de Krimpenerwaard & geen informatie beschikbaar \\
\hline Waterschap Hollandse Delta & geen informatie beschikbaar \\
\hline Waterschap Brabantse Delta & geen informatie beschikbaar \\
\hline Waterschap Scheldestromen & geen informatie beschikbaar \\
\hline Waterschap De Dommel & metadata-file (xml) opgestuurd \\
\hline Waterschap Aa en Maas & informatie ontsloten via eigen website \\
\hline Waterschap Peel en Maasvallei & geen informatie beschikbaar \\
\hline Waterschap Roer en Overmaas & geen informatie beschikbaar \\
\hline
\end{tabular}




\section{Bijlage 3 Handleiding Verstoringsbronnenkaart}

De verstoringsbronnenkaart is te raadplegen op:

http://archeologieinnederland.nl/bronnen-en-kaarten/ 


\section{Bijlage 4 Contactadressen aangeschreven organisaties}

\begin{tabular}{|c|c|c|c|c|c|c|c|c|}
\hline Instantie & Adres & Postcode & Plaats & Internet & Mail & Telefoon & Contactpersoon & e-mail contactpersoon \\
\hline De Grondbank & 2e Daalsedijk $8 \mathrm{~V}$ & $3551 \mathrm{EJ}$ & Utrecht & www.grondbank.nl & info@grondbank.nl & 030-2966485 & & \\
\hline Dienst Rijkswaterstaat & Postbus 2232 & $3500 \mathrm{GE}$ & Utrecht & www.rijkswaterstaat.nl & $\begin{array}{l}\text { Servicedesk Zakelijk } \\
\text { contactformulier }\end{array}$ & 088-7970788 & Jaap Frommé & 08008002@rws.nl \\
\hline N.V. Nederlandse Gasunie & P.O. Box 19 & $9700 \mathrm{MA}$ & Groningen & www.gasunie.nl & communicatie@gasunie.nl & $050-5219111$ & & \\
\hline Provincie Friesland & Postbus 20120 & 8900 HM & Leeuwarden & www.fryslan.frl & provincie@fryslan.nl & $058-2925925$ & & \\
\hline Provincie Groningen & Postbus 610 & $9700 \mathrm{AP}$ & Groningen & www.provinciegroningen.nl & info@provinciegroningen.nl & $050-3164911$ & & \\
\hline Provincie Drenthe & Postbus 122 & $9400 \mathrm{AC}$ & Assen & www.provincie.drenthe.nl & post@drenthe.nl & $0592-365555$ & Theo ten Ascher & T.tenAscher@drenthe.nl \\
\hline Provincie Overijssel & Postbus 10078 & 8000 GB & Zwolle & www.overijssel.nl & postbus@overijssel.nl & 038-4998899 & & \\
\hline Provincie Gelderland & Postbus 9090 & $6800 \mathrm{GX}$ & Arnhem & www.gelderland.nl & provincieloket@gelderland.nl & 026-3599111 & Rien de Bruin & m.de.bruin@gelderland.nl \\
\hline Provincie Flevoland & Postbus 55 & $8200 A B$ & Lelystad & www.flevoland.nl & info@flevoland.nl & $0320-265265$ & David Jansma & d.jansma@ofgv.nl \\
\hline Provincie Noord Holland & Postbus 3007 & 2001 DA & Haarlem & www.noord-holland.nl & post@noord-holland.nl & $023-5143143$ & $\begin{array}{l}\text { Rob van Eerden/06- } \\
18306059\end{array}$ & eerdenr@noord-holland.nl \\
\hline Provincie Zuid Holland & Postbus 90602 & 2509 LP & Den Haag & www.zuid-holland.nl & Contactformulier & $070-4416611$ & Clemens Kester & cgm.kester@pzh.nl \\
\hline Provincie Utrecht & Postbus 80300 & $3508 \mathrm{TH}$ & Utrecht & www.provincie-utrecht.nl & info@provincie-utrecht.nl & $030-2589111$ & E.L. (Eddie) Poppe & Eddie.Poppe@provincie-utrecht.nl \\
\hline Provincie Zeeland & Postbus 6001 & 4330 LA & Middelburg & www.zeeland.nl & provincie@zeeland.nl & $0118-631011$ & C.J. (Kees) Meerman & cj.meerman@zeeland.nl \\
\hline Provincie Brabant & Postbus 90151 & $5200 \mathrm{MC}$ & 's Hertogenbosch & www.brabant.nl & Contactformulier & $073-6812812$ & Ali Raziei & araziei@brabant.nl \\
\hline Provincie Limburg & Postbus 5700 & $6202 \mathrm{MA}$ & Maastricht & www.limburg.nl & Contactformulier & 043-3899999 & Bart Moonen & bj.moonen@prvlimburg.nl \\
\hline Wetterskip Fryslan & Postbus 36 & $8900 \mathrm{AA}$ & Leeuwarden & www.wetterkipfryslan.nl & Contactformulier & 058-2922222 & Ronald Ros & rros@wetterskipfyslan.nl \\
\hline Waterschap Noorderzijlvest & Postbus 18 & $9700 \mathrm{AA}$ & Groningen & www.noorderzijlvest.nl & Contactformulier & 050-3048911 & R. Nieuwenhuis & R.nieuwenhuis@noorderzijlvest.nl \\
\hline Waterschap Reest en Wieden & Postbus 120 & 7940 AC & Meppel & www.reestenwieden.nl & $\begin{array}{l}\text { waterschap@reestenwieden.n } \\
\text { । }\end{array}$ & $0522-276767$ & R. Neijland & R.Neijland@reestenwieden.nl \\
\hline Waterschap Hunze en Aa's & Postbus 195 & $9640 \mathrm{AD}$ & Veendam & www.hunzeenaas.nl & waterschap@hunzeenaas.nl & $0598-693800$ & S. Kooistra & s.kooistra@hunzeenaas.nl \\
\hline Waterschap Vechtstromen & Postbus 5006 & $7600 \mathrm{GA}$ & Almelo & www.vechtstromen.nl & info@vechtstromen.nl & $088-2203333$ & $\begin{array}{l}\text { Gerda Zanting- } \\
\text { Boertien }\end{array}$ & g.zanting@vechtstromen.nl \\
\hline Waterschap Groot Salland & Postbus 60 & $8000 \mathrm{AB}$ & Zwolle & www.wgs.nl & info@wgs.nl & $038-4557200$ & de heer J. Buitenkamp & j.buitenkamp@wgs.nl \\
\hline Waterschap Zuiderzeeland & Postbus 229 & $8200 \mathrm{AE}$ & Lelystad & www.zuiderzeeland.nl & waterschap@zuiderzeelanc & $0320-274911$ & & \\
\hline
\end{tabular}




\begin{tabular}{|c|c|c|c|c|c|c|c|c|}
\hline Instantie & Adres & Postcode & Plaats & Internet & Mail & Telefoon & Contactpersoon & e-mail contactpersoon \\
\hline Waterschap Rijn en Ijssel & Postbus 148 & $7000 \mathrm{AC}$ & Doetinchem & www.wrij.nl & info@wrij.nl & 0314-369369 & $\begin{array}{l}\text { Henk Kerkwijk/ } \\
\text { Bart Breukink }\end{array}$ & $\begin{array}{l}\text { h.kerkwijk@wrij.nl; } \\
\text { b.breukink@wrij.nl }\end{array}$ \\
\hline Waterschap Vallei en Veluwe & Postbus 4142 & $7320 \mathrm{AC}$ & Apeldoorn & www.vallei-veluwe.nl & info@vallei-veluwe.nl & $055-5272911$ & Michiel Nieuwenhuis & Mnieuwenhuis@Vallei-Veluwe.nl \\
\hline HH Hollands Noorderkwartier & Postbus 250 & 1700 AG & Heerhugowaard & www.hhnk.nl & Contactformulier & $072-5828282$ & & \\
\hline $\begin{array}{l}\text { Waterschap Amstel, Gooi en } \\
\text { Vecht }\end{array}$ & Postbus 94370 & $1090 \mathrm{GJ}$ & Amsterdam & www.agv.nl & www.waternet.nl & $088-9394000$ & & \\
\hline $\mathrm{HH}$ van Rijnland & Postbus 156 & $2300 \mathrm{AD}$ & Leiden & www.rijnland.net & post@rijnland.net & $071-3063063$ & Mevr. R. Vink & rona.vink@rijnland.net \\
\hline HH De Stichtse Rijnlanden & Postbus 550 & 3990 GJ & Houten & www.hdsr.nl & post@hdsr.nl & $030-6345700$ & Remco Lots & lots.rfb@hdsr.nl \\
\hline Waterschap Rivierenland & Postbus 599 & $4000 \mathrm{AN}$ & Tiel & $\begin{array}{l}\text { www.waterschaprivierenland. } \\
\mathrm{nl}\end{array}$ & info@wsrl.nl & 0344-649090 & Arjan J. de Bruine & A.de.Bruine@wsrl.nl \\
\hline HH van Delfland & Postbus 3061 & $2601 \mathrm{DB}$ & Delft & www.hhdelfland.nl & info@hhdelfland.nl & $015-2608108$ & de heer G. Gelling & ggelling@hhdelfland.nl \\
\hline $\begin{array}{l}\text { HH van Schieland en de } \\
\text { Krimpenerwaard }\end{array}$ & Postbus 4059 & $3006 \mathrm{AB}$ & Rotterdam & $\begin{array}{l}\text { www.schielandendekrimpener } \\
\text { waard.nl }\end{array}$ & info@hhsk.nl & $010-4537200$ & Peter van Duijvendijk & p.van.duijvendijk@hhsk.nl \\
\hline Waterschap Hollandse Delta & Postbus 4103 & 2980 GC & Ridderkerk & www.wshd.nl & 2005005@wshd.nl & $088-9743000$ & & \\
\hline Waterschap Brabantse Delta & Bouvignelaan 5 & $4836 \mathrm{AA}$ & Breda & www.brabantsedelta.nl & Contactformulier & $076-5641000$ & $\begin{array}{l}\text { Lisette Lycklama à } \\
\text { Nijeholt-Sonke }\end{array}$ & I.lycklama@brabantsedelta.nl \\
\hline Waterschap Scheldestromen & Postbus 1000 & $4330 \mathrm{ZW}$ & Middelburg & www.scheldestromen.nl & info@scheldestromen.nl & $088-2461000$ & Geert Boekema & $\begin{array}{l}\text { Geert.Boekema@Scheldestromen } \\
\text {.nl }\end{array}$ \\
\hline Waterschap De Dommel & Postbus 10.001 & $5280 \mathrm{DA}$ & Boxtel & www.dommel.nl & info@dommel.nl & $0411-618618$ & Eric Jonkergouw & Ejonkergouw@dommel.nl \\
\hline Waterschap Aa en Maas & Postbus 5049 & $5201 \mathrm{GA}$ & 's Hertogenbosch & www.aaenmaas.nl & info@aaenmaas.nl & $088-1788000$ & Lambik Swinkels & Lswinkels@aaenmaas.nl \\
\hline $\begin{array}{l}\text { Waterschap Peel en } \\
\text { Maasvallei }\end{array}$ & Postbus 3390 & $5902 \mathrm{RJ}$ & Venlo & www.wpm.nl & info@wpm.nl & 077-3891111 & Frank Arts & Frank.Arts@wpm.nl \\
\hline $\begin{array}{l}\text { Waterschap Roer en } \\
\text { Overmaas }\end{array}$ & Postbus 185 & $6130 \mathrm{AD}$ & Sittard & www.overmaas.nl & info@overmaas.nl & $046-4205700$ & Raoul Adjobo & r.adjobo@overmaas.nl \\
\hline
\end{tabular}


Wageningen Environmental Research Postbus 47

6700 AA Wageningen

T 0317480700

www.wur.nl/environmental-research

Wageningen Environmental Research

Rapport 2751

ISSN 1566-7197
De missie van Wageningen University \& Research is 'To explore the potential of nature to improve the quality of life'. Binnen Wageningen University \& Research bundelen Wageningen University en gespecialiseerde onderzoeksinstituten van Stichting Wageningen Research hun krachten om bij te dragen aan de oplossing van belangrijke vragen in het domein van gezonde voeding en leefomgeving. Met ongeveer 30 vestigingen, 5.000 medewerkers en 10.000 studenten behoort Wageningen University \& Research wereldwijd tot de aansprekende kennisinstellingen binnen haar domein. De integrale benadering van de vraagstukken en de samenwerking tussen verschillende disciplines vormen het hart van de unieke Wageningen aanpak. 



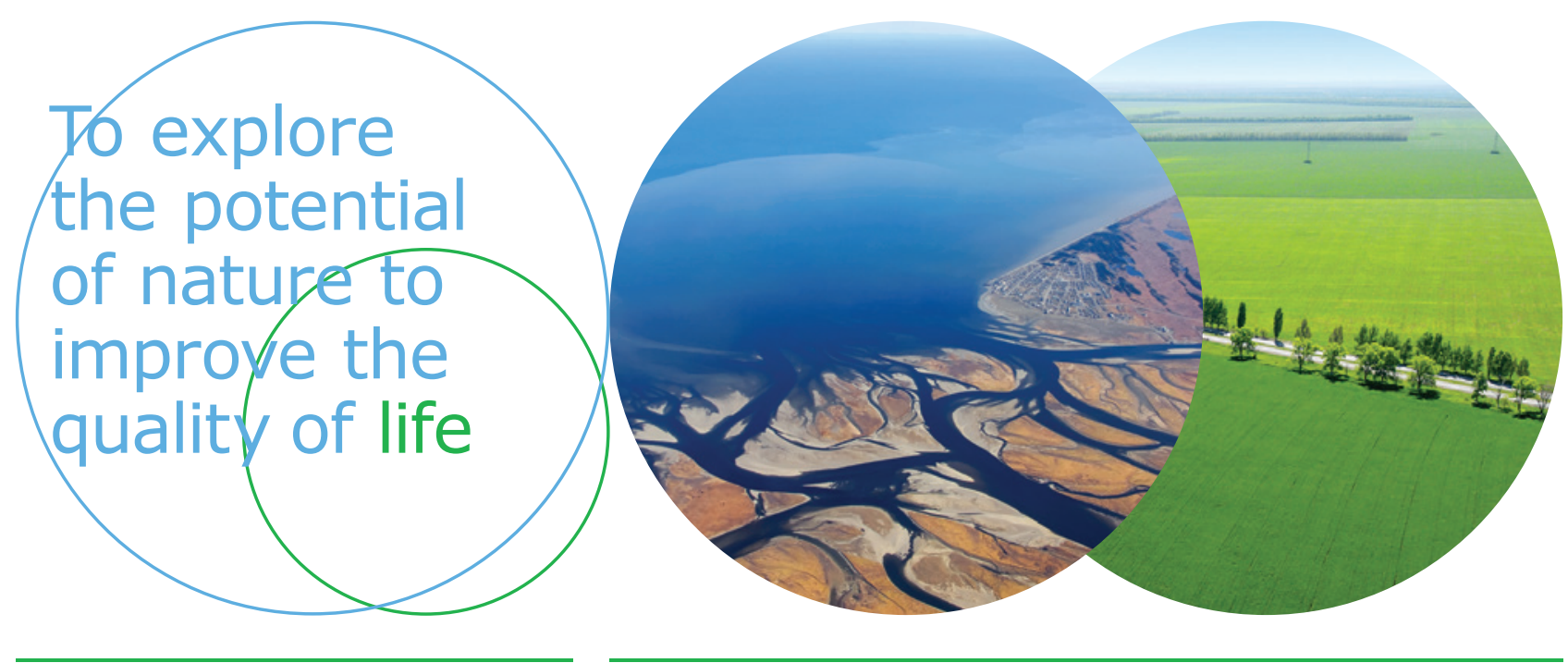

Wageningen Environmental Research Postbus 47

$6700 \mathrm{AB}$ Wageningen

T 317480700

www.wur.nl/environmental-research

Rapport 2751

ISSN 1566-7197
De missie van Wageningen University \& Research is 'To explore the potential of nature to improve the quality of life'. Binnen Wageningen University \& Research bundelen Wageningen University en gespecialiseerde onderzoeksinstituten van Stichting Wageningen Research hun krachten om bij te dragen aan de oplossing van belangrijke vragen in het domein van gezonde voeding en leefomgeving. Met ongeveer 30 vestigingen, 5.000 medewerkers en 10.000 studenten behoort Wageningen University \& Research wereldwijd tot de aansprekende kennisinstellingen binnen haar domein. De integrale benadering van de vraagstukken en de samenwerking tussen verschillende disciplines vormen het hart van de unieke Wageningen aanpak. 